\title{
Flexibility versus Stability: A difficult tradeoff in the Eurozone
}

\author{
Paul De Grauwe \\ London School of Economics \\ Yuemei Ji \\ University College London
}

\begin{abstract}
:
The optimal currency areas (OCA) theory has been influential in pushing eurozone countries towards structural reforms to make product and labour markets more flexible. The underlying assumption of the OCA prescription for structural reform is that asymmetric shocks are permanent. However, when shocks are temporary it does not follow that more flexibility is the answer. When shocks are the result of business cycle movements, the way to deal with them is by stabilisation efforts. We provide empirical evidence that suggests that the biggest shocks in the eurozone were the result of business cycle movements. These were relatively well synchronised, except for their amplitude. We argue that efforts to stabilise the business cycles should be strengthened relative to the efforts that have been made to impose structural reforms, and consider the implications for the governance of the eurozone.
\end{abstract}

We are grateful for the financial support provided by the European Commission's Horizon 2020 Firstrun Project. We also gratefully acknowledge the comments and suggestions from Daniel Gros, Frank Vandenbroucke, and anonymous referees. 


\section{Introduction}

Since the eruption of the sovereign debt crisis in the eurozone, substantial efforts have been made to create a new form of governance for the eurozone that will make the monetary union more robust in absorbing future economic and financial shocks. Much of the drive to adapt the governance of the eurozone has been influenced by the traditional theory of optimal currency areas (OCA), which stresses the need for flexibility in product and labour markets. As a result, the eurozone countries have been pushed towards structural reforms that aim to reduce the structural rigidities in product and labour markets, in the hope that this would lead to a more resilient monetary union capable of withstanding future asymmetric shocks.

Figure 1, which presents the OECD product market legislation index, shows that the eurozone countries have introduced structural reforms at a faster pace than the rest of the OECD countries. Figure 2, which presents the OECD index of employment protection, shows how the eurozone has significantly reduced its tight employment protection, especially since the sovereign debt crisis in 2010. It is interesting to note that since the early 1990s the non-eurozone OECD countries have followed a reverse trend of increasing employment protection.

In this paper we ask whether this movement towards structural reform as part of the push for new governance is really going in the right direction. We will argue that this is not the case. The main reason is that the nature of the shocks that have hit the eurozone does not correspond to the pattern of asymmetric shocks that has been identified by the OCA theory to require more flexibility. We will argue that what is needed in the eurozone is not more structural reforms but a better mechanism capable of dealing with the classical boom and bust dynamics that are inherent to capitalism.

Hyman Minsky's (1986) classic analysis of booms and busts in capitalist systems stresses the need to stabilise government mechanisms. We will ask whether the eurozone, which has moved towards more flexibility, provides for this stabilising mechanism. 
In sections 2 and 3, we analyse what the OCA theory has to say about the need for flexibility and stabilisation in the face of asymmetric shocks. In section 4 we analyse empirically the nature of these shocks in the eurozone and in section 5 we study what this evidence might means for the governance of the eurozone.

\section{Figure 1. Product market legislation index}

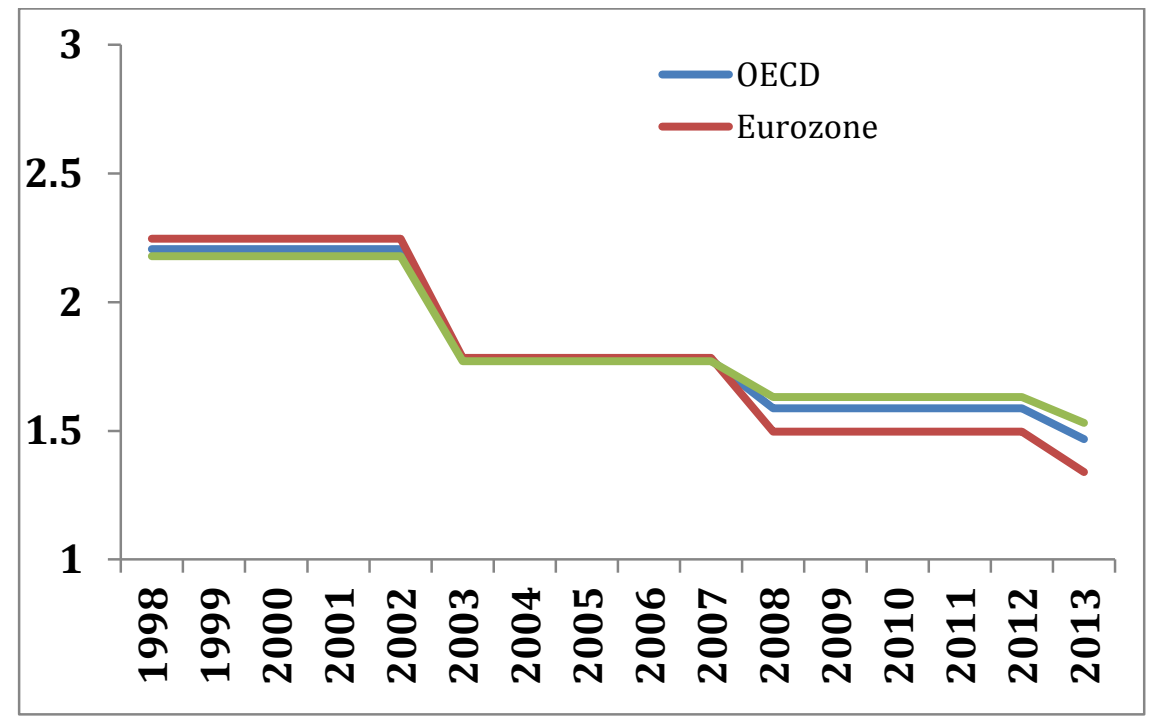

Source: OECD.

Figure 2. Employment protection legislation index

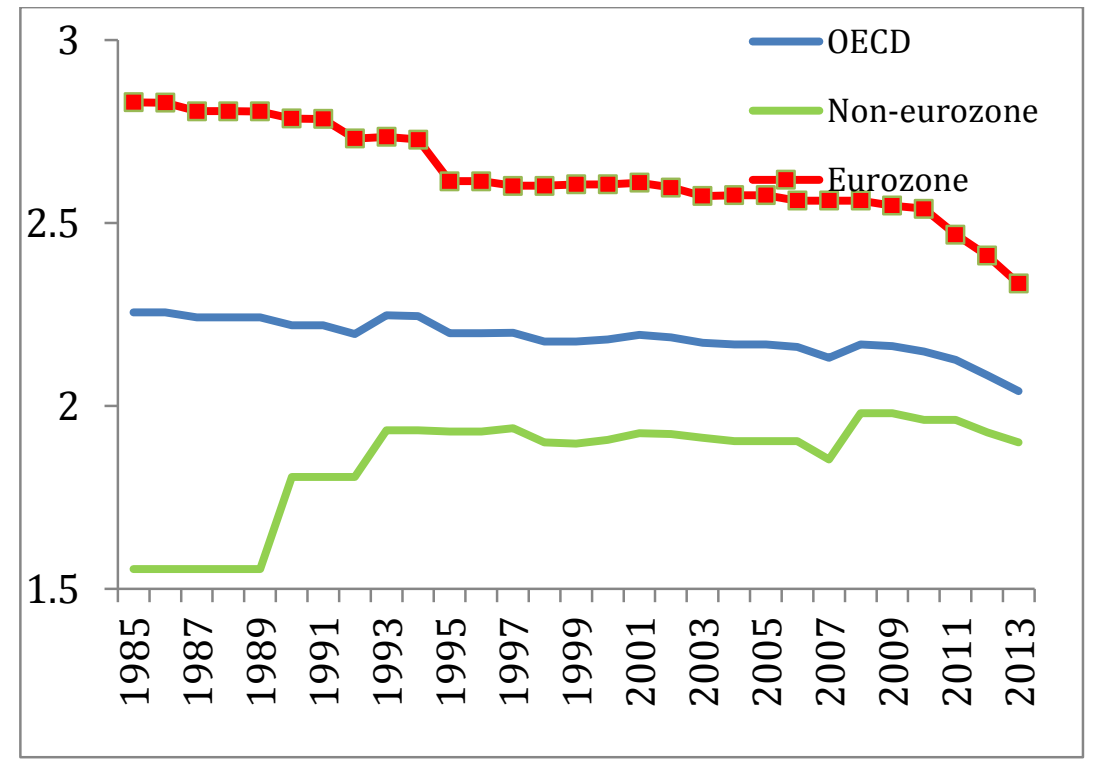

Source: OECD. 


\section{Standard OCA theory and the governance of the eurozone}

The theory of optimal currency areas (OCA) has created a set of ideas that has an significant influence on the governance of the eurozone and on views about how this governance should be strengthened in the future. The best way to make this clear is to present the core of the OCA theory, using a well-known graphical representation of this theory (see De Grauwe (2014)). This is done in Figure 3. On the horizontal axis we set out the degree of flexibility in the labour and goods markets. This measures the degree to which wages and prices adjust freely to shocks and the degree to which workers are mobile. We assume that these different dimensions of flexibility can be represented by one index. On the vertical axis we set out the degree of symmetry between countries, i.e. the degree of co-movement (correlation) of macroeconomic variables such as output and employment. Thus, when there are a lot of asymmetric shocks we move downwards along the vertical axis. By contrast, when shocks become less asymmetric we move upwards along the vertical axis.

The downward sloping OCA line represents the trade-off between symmetry and flexibility. Hence, when the degree of symmetry declines (there are more asymmetric shocks) countries in a monetary union need more flexibility to deal with these shocks. The OCA-line separates the space into two zones. The OCAzone above the OCA-line contains the collection of points at which symmetry and flexibility are high enough to guarantee that the benefits of the monetary union exceed the costs. The points below the OCA-line are the points at which symmetry and flexibility are too low, i.e. countries located in that zone will find that the costs of the monetary union exceed the benefits. The OCA-line that separates the two zones can therefore also be defined as the collection of points for which the benefits and the costs of the monetary union are equal.

This theory has been very influential for the governance of the eurozone and continues to be so. It is at the core of the policy prescriptions that call for structural reforms so as to make the labour and goods markets more flexible. In fact, since the start of the sovereign debt crisis in 2010 member countries have been pressured by the European Commission to introduce a whole set of 
structural reforms. The member countries that turned to the eurozone for financial support (Greece, Ireland, and Portugal) were given this support conditional on introducing a series of structural reforms that would make labour and goods markets more flexible. The underlying rationale was the OCA theory that stresses the need for flexibility to deal with asymmetric shocks in a monetary union.

Figure 3. OCA theory tradeoff between symmetry and flexibility

\section{Symmetry}

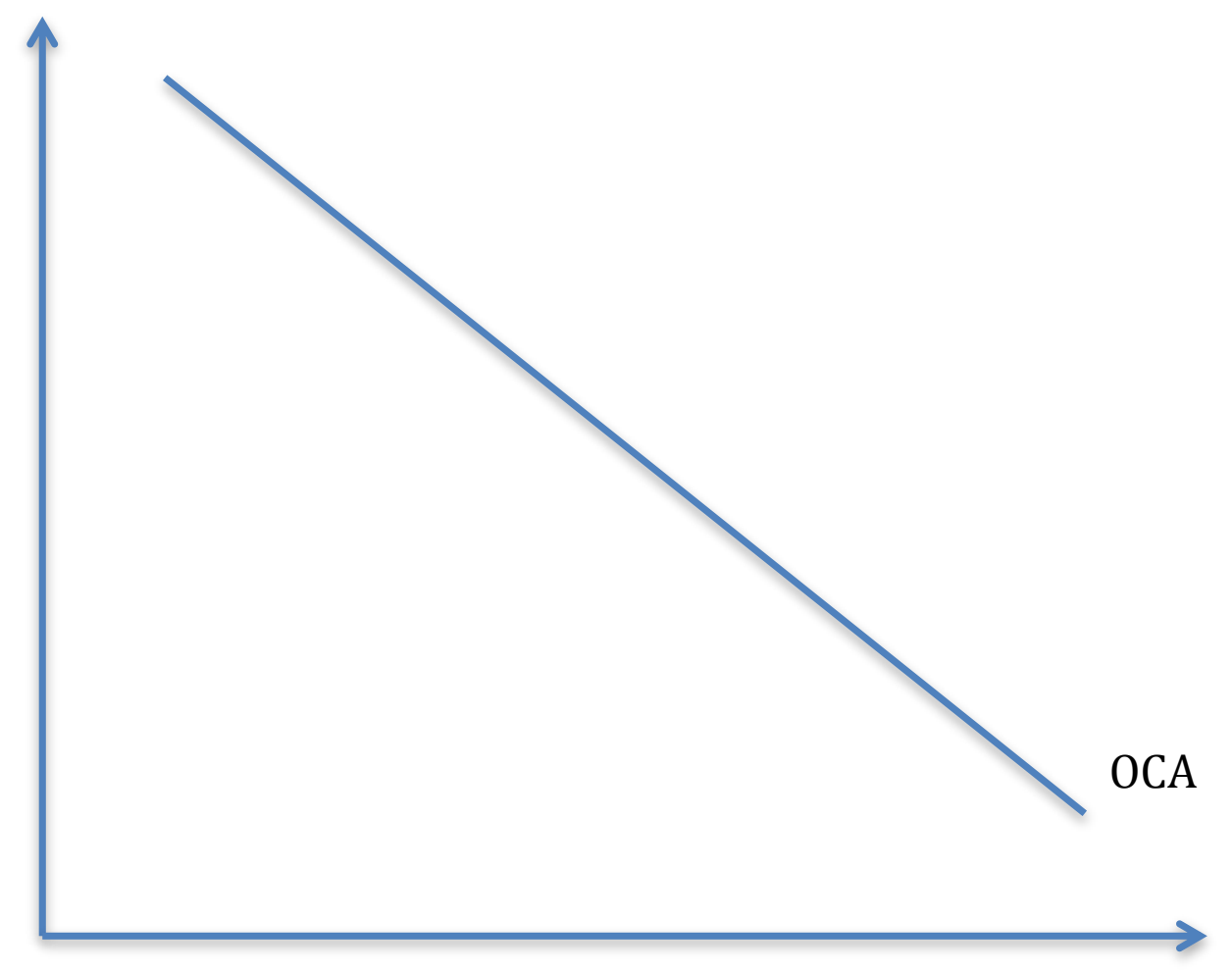

Flexibility

One of the underlying assumptions of this theory and its prescription for flexibility is that the asymmetric shocks are permanent. When shocks are permanent, e.g. a change in preferences that leads consumers in one country to buy more of the foreign than of the domestic good, or a productivity increase in one but not in another country, then there is really no other way in a monetary 
union to deal with such a shock other than changing relative prices (wages or product prices) or by a movement of labour and capital.

Things are very different, however, when shocks are temporary. In that case, it can be argued that flexibility is not necessary. In fact it can even be harmful. Take the case of business cycle movements. When these are asymmetric, i.e. when they are not synchronised, it makes little sense to adjust by relative price changes and/or by movements of labour and capital. Flexibility may in fact exacerbate the business cycle movements and its asymmetry. For example, if country A experiences a recession and country B a boom the movement of labour from $A$ to $B$ is likely to exacerbate the recession in country A and the boom in country B. Or take flexibility of wages. If during the recession country A is forced to reduce wages, the immediate effect of the wage cuts will be a decline in aggregate demand, which will make the recession in country A more severe.

From the preceding analysis it follows that temporary shocks, such as business cycle movements, should be dealt with differently, i.e. by stabilisation efforts that smooth consumption over time.

However, the OCA theory that focuses on the trade-off between flexibility and symmetry was developed on the assumption that asymmetric shocks are permanent. These shocks are also typically exogenous, like meteor impacts. There is nothing one can do about these. One is forced to adjust by making the system more flexible.

Business cycle shocks, by contrast, can be said to be endogenous. They are the result of endogenous movements in optimism and pessimism that lead to booms and busts. These movements have been endemic in capitalism and will continue to do their work also in a monetary union. They have been described by Minsky (1986) and Kindleberger (2001). To the extent that these movements are not synchronised, they do not call for more flexibility; rather they call for insurance mechanisms that allow countries experiencing a downturn to be compensated by countries that experience a boom, in such a way that when the fortunes of countries are reversed the transfers are reversed. 
It has long been recognised that such an insurance mechanism requires some form of budgetary union. Thus, endogenous and asymmetric business cycle movements call for very different institutions in the union from the permanent and exogenous shocks that have been at the core of the OCA analysis.

\section{Governance of a monetary union in the face of temporary shocks}

In this section we consider what the nature of the institutions of a monetary union should be when the shocks are endogenous, temporary and asymmetric. We will focus on business cycle movements that are driven by 'animal spirits', i.e. movements of optimism and pessimism that lead to booms during periods of optimism and recessions during periods of pessimism. In this section we focus on the theory. In the next section we analyse the empirical question of the nature of the asymmetric shocks in the eurozone.

We start from a similar tradeoff to the one in Figure 3, but now we concentrate on the tradeoff between flexibility and budgetary union. A budgetary union should be seen as an insurance mechanism that allows countries experiencing bad economic times to be compensated by countries that fare well.

The way this tradeoff is constructed is as follows (Figure 4). On the vertical axis we set out the degree of budgetary union. The higher the degree of budgetary union the more we move upwards along the vertical line. On the horizontal axis we set out the same measure of flexibility as that used in figure 3. The OCAs line now measures the minimum combinations of budgetary union and flexibility needed to make a monetary union economically attractive (higher benefits than costs). It is negatively sloped for the following reason. When budgetary union increases, insurance against asymmetric shocks increases, making monetary union less costly. As a result, there is less need for flexibility. We move upward along the negatively sloped OCAs line. ${ }^{1}$

This is an important insight. Flexibility may sound great for many economists and central bankers, but it is costly for those people who are forced to be flexible.

\footnotetext{
${ }^{1}$ We call this tradeoff the OCAs line because the idea of such a tradeoff comes from André Sapir (2015).
} 
Flexibility means that these people may have to accept a wage cut or be forced to emigrate. We learn from Figure 4 that a movement towards budgetary union alleviates the (painful) need to be flexible. It may also make a monetary union more acceptable to large segments of the population.

\section{Figure 4. Tradeoff between budgetary union and flexibility}

\section{Budgetary union}

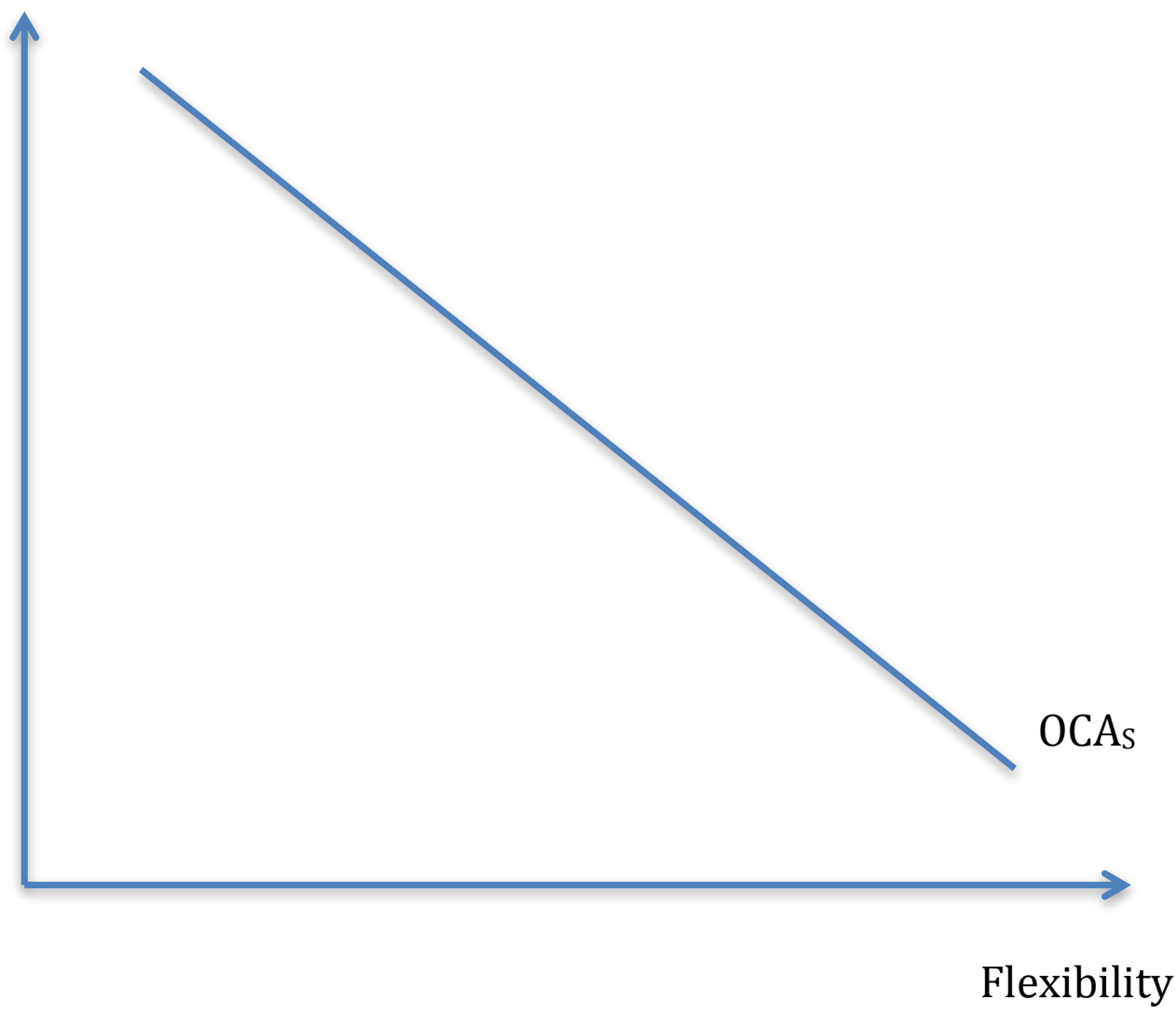

We can use the insights of Figure 4 to analyse the importance of the nature of the asymmetric shocks. We have made the distinction between asymmetric shocks that are exogenous and permanent, and asymmetric shocks that are temporary and endogenous. We have argued that when a permanent (exogenous) shock occurs flexibility is the only option to adjust to this shock. By contrast, when business cycle movements are desynchronised it is not optimal to use flexibility. In that case an insurance mechanism is the appropriate way to govern the monetary union. A budgetary union provides this. 
It can now be shown that the nature of the shocks influences the slope of the tradeoff. ${ }^{2}$ When the shocks are mainly of the permanent type, we obtain a steep tradeoff. We show this in Figure 5. We have also put the eurozone of 19 members below the OCAs-line, suggesting that the present eurozone is not an optimal currency area. The steep tradeoff implies that a small increase in flexibility leads us quicker into the OCA zone than a budgetary union. In the most extreme case, i.e. when all shocks are of a permanent nature, the tradeoff becomes vertical. In that case no amount of budgetary union will bring us into the OCA-zone. There is then no other way but to increase flexibility.

Figure 5. How to move the eurozone towards the OCAs-area when permanent shocks dominate?

\section{Budgetary union}

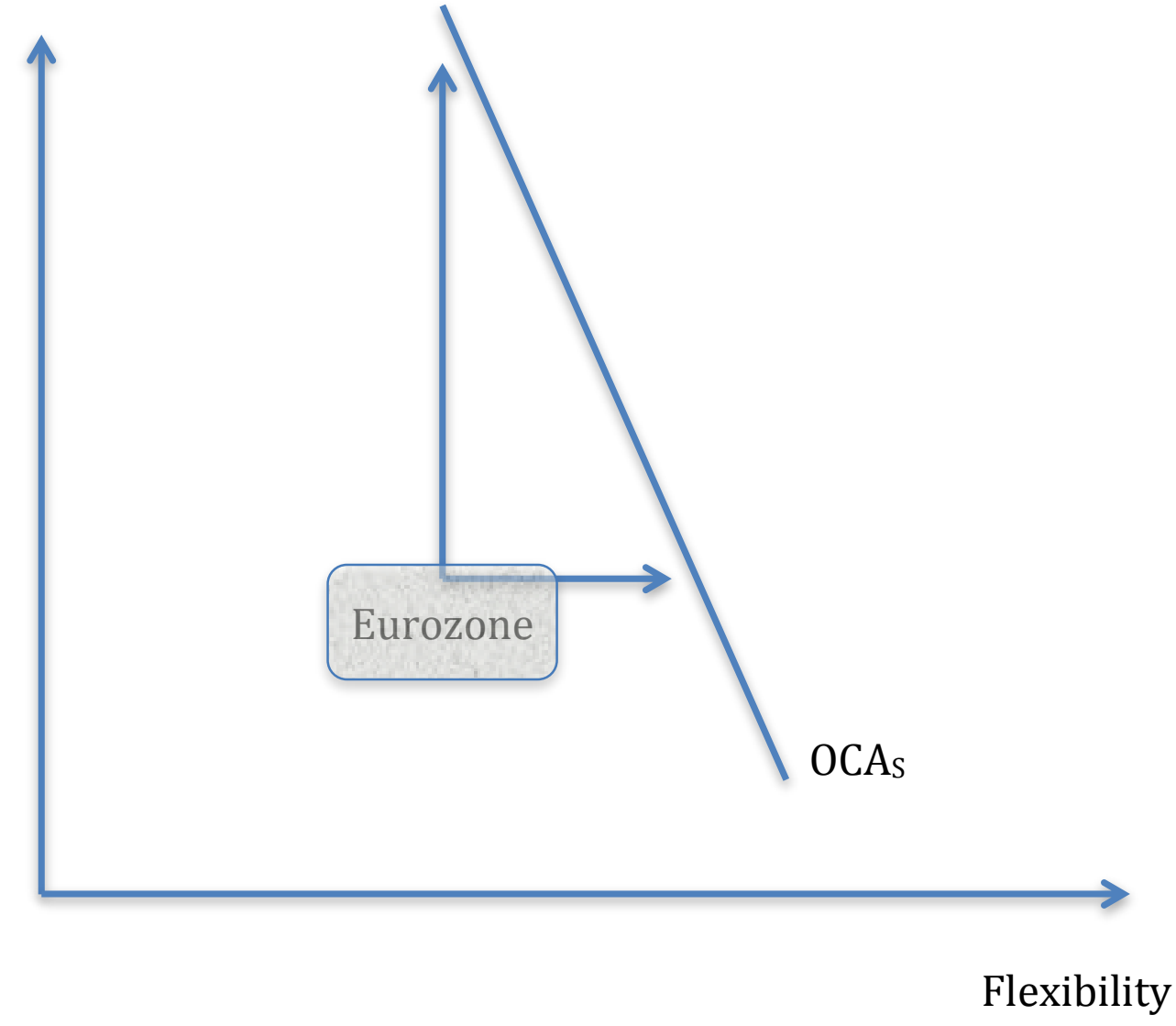

2 We are grateful to Frank Vandenbroucke for suggesting that the nature of the shocks affects the slope of the tradeoff. 
Things are very different when the shocks are temporary, driven by business cycle movements. In that case the tradeoff is flat (Figure 6). As a result, much flexibility is needed to move the eurozone into the OCA area compared to budgetary union. A relatively small increase in budgetary union will bring us into the OCA-zone. In the most extreme case, i.e. when all shocks are of a temporary nature,, the tradeoff is horizontal. In that case no amount of flexibility will succeed in bringing the eurozone into the OCA-zone. The only way to achieve optimality will be through a budgetary union.

Figure 6. How to move the eurozone towards the OCAs-area when business cycle movements dominate?

\section{Budgetary union}

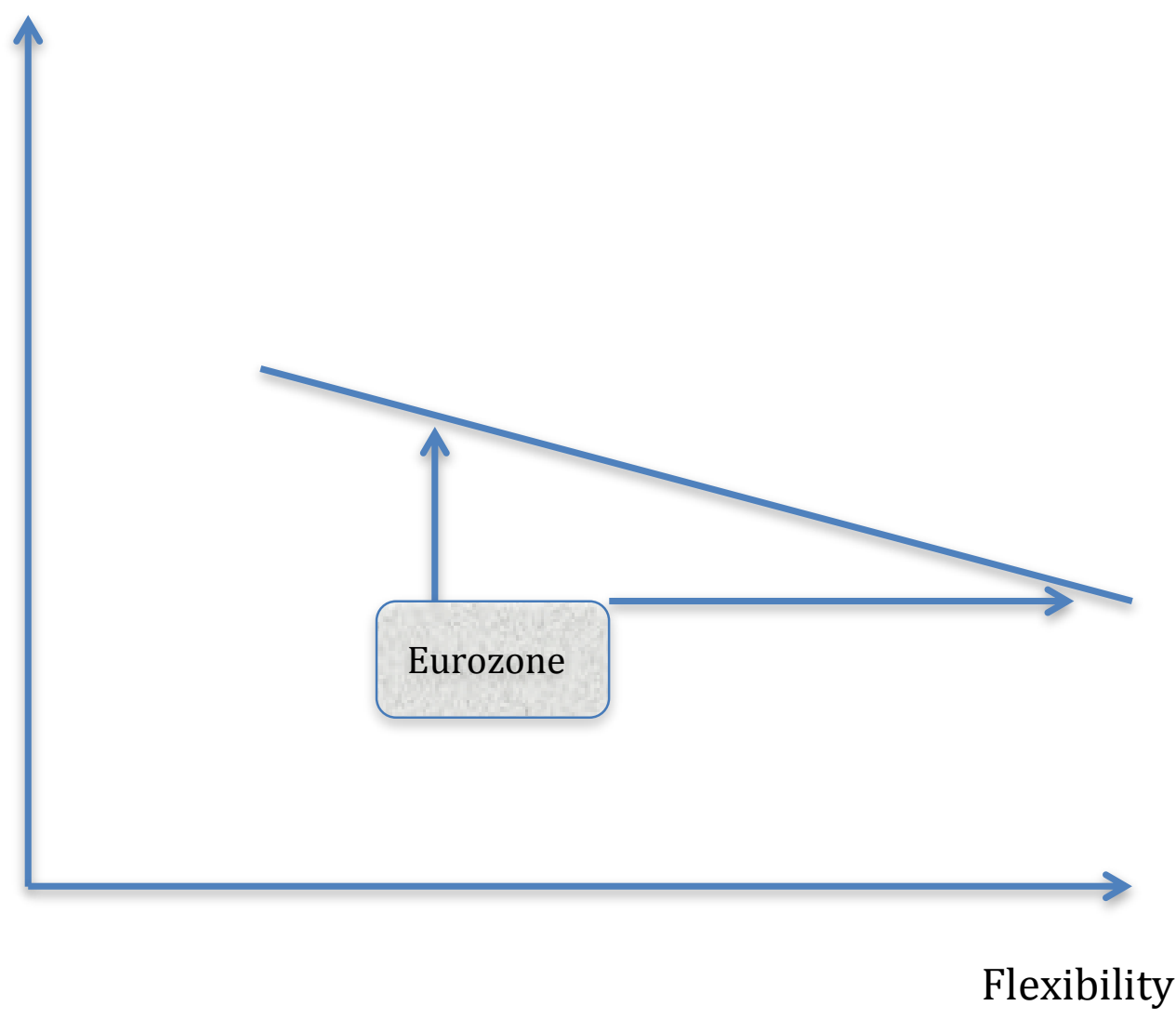

One complication that arises here has to do with hysteresis. Sometimes temporary shocks can lead to hysteresis effects. For example, a recession typically leads to plant closures and dismissal of workers. To the extent that 
these workers have developed firm specific skills that are lost when the firm disappears, the workers lose part of their human capital making it difficult to find another (comparable) job. Unemployment can then become protracted. Another example relates to the nature of the boom. If, as was the case in Ireland and Spain, the boom is concentrated in the housing market, many workers are attracted to this sector during the boom. After the crash they are dismissed. They may find it difficult to use their skills acquired in the housing market in other sectors of the economy. There is a large literature on sources of hysteresis (See Blanchard, et al.(1986), Ball(2009), Fatas and Summers(2015)).

The existence of hysteresis has implications for our discussion. It implies that if a business cycle shock occurs it matters a great deal to try to use stabilization so as to avoid hysteresis effects. If temporary business cycle shocks have permanent effects the need to set up schemes that will mitigate the impact of these shocks becomes even more important.

Figures 5 and 6 lead to another interesting insight. Flexibility in labour markets is something national governments can do. There is no need for further integration to increase flexibility. Budgetary union, however, is of a different nature. It requires political integration. In other words, while flexibility is in the realm of national governments, budgetary union is a European affair (Sapir (2015)). Thus, when shocks are permanent they have to be dealt with at the national level while when shocks are temporary the response should be at the level of the eurozone. 


\section{The nature of shocks in the eurozone: empirical evidence}

It is not always easy to separate permanent from temporary shocks in economic time series. Here we use a Hodrick-Prescott filter (HP) that allows us to estimate the long-term trend component in GDP. The cyclical component is obtained by subtracting the trend component from the observed $\mathrm{GDP}^{3}$ (for more detail, see appendix, where we also analyse the robustness of the results for changes in the smoothness parameter lambda in the HP filter).

The results of this exercise are shown in Figure 7. We present, for each eurozone country, ${ }^{4}$ trend growth and the observed growth rates (the cyclical component is obtained by subtracting the observed from the trend growth). Two results stand out. First, we observe for all eurozone countries (except for Germany) a decline in the long-term growth rate of GDP. This decline is particularly significant in Greece, Ireland, Finland, Spain, Portugal and Italy. Second, there is great variability in the business cycle (temporary) component of GDP growth. In order to gauge the relative importance of cyclical and trend components in GDP growth we compare the mean (absolute) ${ }^{5}$ cyclical growth of GDP with the (absolute) mean trend growth of GDP for each country. We show the results in Table 1. We observe that for the core countries (Austria, Belgium, Germany, and the Netherlands) the cyclical growth and trend growth components are of similar magnitudes, although the cyclical component is systematically larger than the trend component. In the countries of the periphery (Spain, Portugal, Ireland, Italy, and Greece) this is very different. We observe that for these countries the cyclical growth component is much larger than the trend growth component (the most extreme case being observed for Greece). Thus, in the peripheral countries the GDP growth rates have been dominated by cyclical movements in economic activity of the boom-bust type.

\footnotetext{
${ }^{3}$ There is a literature based on Blanchard and Quah (1989) that is based on estimating a VAR and, after imposing identifying restrictions, is able to estimate the temporary and the permanent component in output shocks. We discuss this literature in section 5 .

${ }^{4}$ We only include the original eurozone countries. The new eurozone countries entered too late to provide a sufficiently long time series.

${ }^{5}$ As the cyclical component alternates between positive and negative numbers we have to take the absolute values.
} 
Figure 7. Cyclical and trend components in GDP growth (1999-2014)

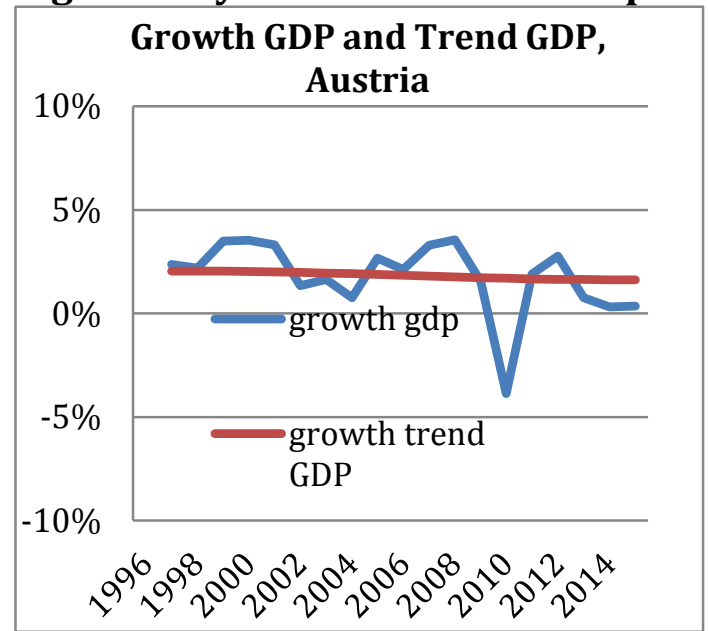

Growth GDP and Trend GDP, Belgium
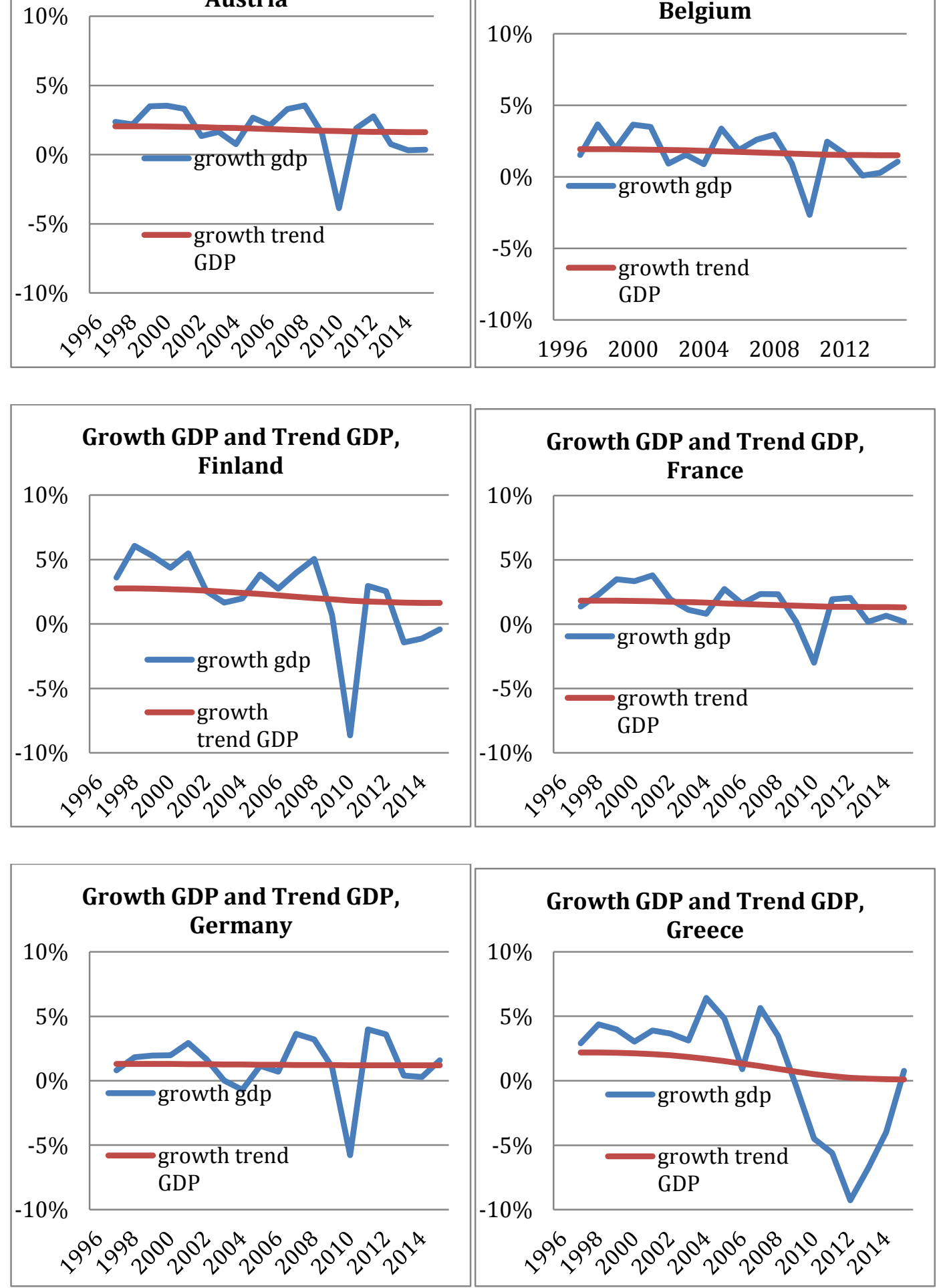

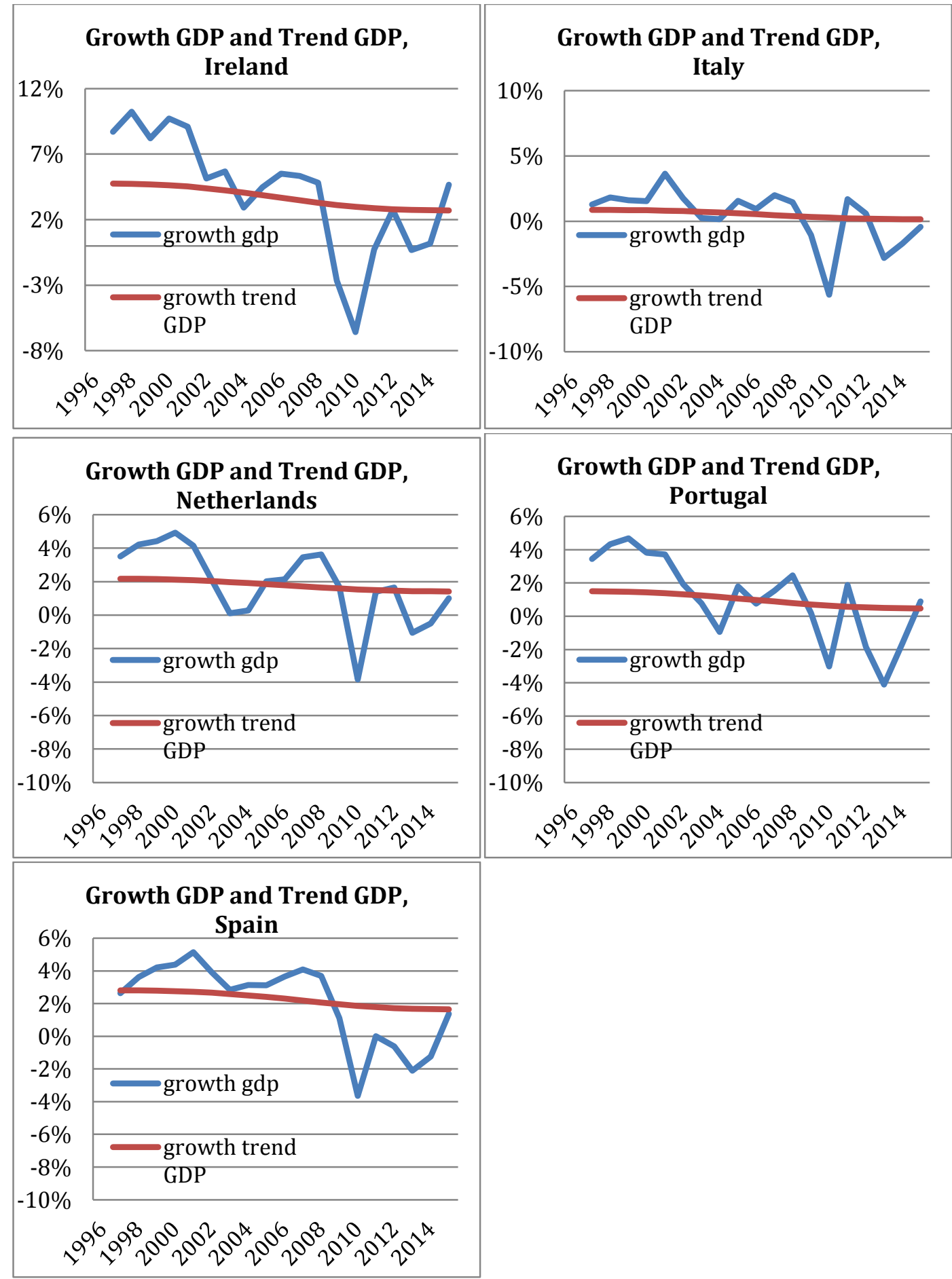

Sources: Eurostat and own calculations. 
Table 1. Mean (absolute) trend growth and mean (absolute) business cycle change in GDP (in percent) during 1999-2014

\begin{tabular}{|l|ccc|}
\hline & $\begin{array}{c}\text { Mean } \\
\text { cycle }\end{array}$ & $\begin{array}{c}\text { Mean } \\
\text { trend }\end{array}$ & ratio \\
\hline Austria & $1,79 \%$ & $1,77 \%$ & 1,01 \\
Belgium & $1,72 \%$ & $1,67 \%$ & 1,03 \\
Germany & $1,55 \%$ & $1,23 \%$ & 1,26 \\
France & $2,15 \%$ & $1,49 \%$ & 1,44 \\
Netherlands & $2,66 \%$ & $1,66 \%$ & 1,60 \\
Finland & $4,35 \%$ & $2,02 \%$ & 2,15 \\
Spain & $4,58 \%$ & $2,07 \%$ & 2,21 \\
Ireland & $8,01 \%$ & $3,35 \%$ & 2,39 \\
Portugal & $3,67 \%$ & $0,81 \%$ & 4,53 \\
Italy & $2,86 \%$ & $0,41 \%$ & 7,05 \\
Greece & $9,09 \%$ & $0,90 \%$ & 10,11 \\
\hline
\end{tabular}

Source: Computations based on data from Eurostat.

What are the implications of these results? First, since the start of the eurozone, cyclical (temporary) movements have been the dominant factor behind growth variations in GDP. This is especially the case in those peripheral countries where cyclical movements in economic growth are many times higher than the longterm growth rates. Thus, as mentioned earlier, booms and bust in economic activity seems to be the overwhelming characteristic of movements in GDP in the countries of the periphery.

Second, it appears that the cyclical movements of GDP are highly correlated in the eurozone. This is made clear by Table 2 , which shows the correlations in the cyclical components of GDP growth across the eurozone. We observe high correlation coefficients of bilateral cyclical components of GDP growth, typically 0.8 or more. It is interesting to note that the country with the lowest correlation coefficients is Germany (although the German correlation coefficients are all positive). Thus, one can conclude that the business cycles of the eurozone countries were highly correlated. Germany stands out as the country with the lowest (positive) correlations of its business cycle with the rest of the eurozone. 
Table 2. Correlation coefficients of cyclical components of GDP growth

\begin{tabular}{|lrrrrrrrrrr|}
\hline & Austria & Belgium & Finland & France & Germany & Greece & Ireland Italy & Netherl Port \\
Austria & & & & & & & & & & \\
Belgium & 0,97 & & & & & & & & \\
Finland & 0,97 & 0,98 & & & & & & & \\
France & 0,93 & 0,95 & 0,97 & & & & & & & \\
Germany & 0,69 & 0,57 & 0,55 & 0,59 & & & & & \\
Greece & 0,73 & 0,82 & 0,84 & 0,74 & 0,09 & & & & \\
Ireland & 0,85 & 0,89 & 0,92 & 0,95 & 0,41 & 0,81 & & & \\
Italy & 0,91 & 0,96 & 0,98 & 0,96 & 0,50 & 0,86 & 0,93 & & \\
Netherlands & 0,93 & 0,94 & 0,93 & 0,91 & 0,60 & 0,75 & 0,86 & 0,90 & \\
Portugal & 0,98 & 0,89 & 0,89 & 0,87 & 0,37 & 0,82 & 0,87 & 0,90 & 0,94 & \\
Spain & 0,85 & 0,91 & 0,94 & 0,87 & 0,27 & 0,97 & 0,90 & 0,95 & 0,86 & 0,90 \\
\hline
\end{tabular}

Source: Own calculations based on Eurostat.

Thus, the asymmetry between the eurozone countries is to be found not so much in a lack of correlation in business cycle movements but in the intensity of the boom-bust dynamics of growth rates. Put differently, eurozone countries' business cycles seem to have been relatively well correlated. The difference between these countries was that some (mainly in the periphery) experienced much higher variance in business-cycle fluctuations than others (in the core). As a result, the asymmetry between member countries is to be found in the variance of the business cycles. This feature is striking in Figure 8, which shows the movements of the business-cycle components in the different eurozone countries. These appear to move together but are of very different amplitude. Some countries like Ireland and Spain experience a very strong boom and later bust, while countries like Belgium, Austria and Germany experience similar cycles but of much less amplitude.

In order to obtain a more precise estimate of the asymmetry in the amplitudes of the business cycles, we regressed each country's domestic cyclical component on the eurozone common cyclical component. The estimated slope coefficients reveal the extent to which the domestic cycles are smaller or lower in amplitude than the common cycle. The estimated slope coefficients are presented in Table 3. It is striking to find how different these slope coefficients are. Germany, Belgium, Austria and France have slope coefficients that are significantly lower than 1, suggesting cycles of significantly lower amplitude than the euro-cycle. 
Conversely, Finland, Spain, and especially Ireland and Greece, have slope coefficients significantly higher than 1 . This suggests that these countries experienced much higher amplitudes in their business cycles than the common euro-cycle.

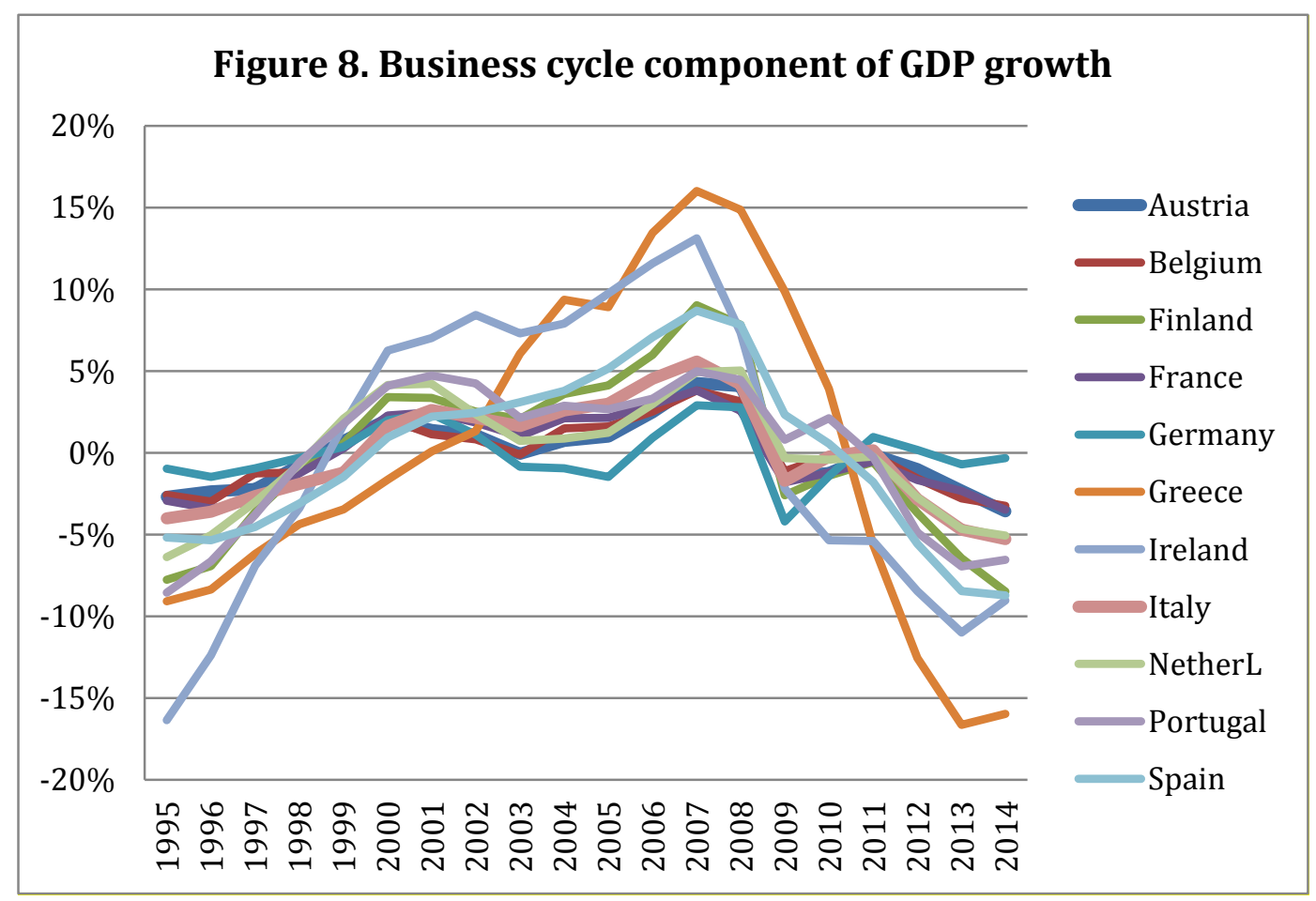

Source: Own calculation based on Eurostat.

Table 3. Slope of regression domestic cycle on euro-cycle

\begin{tabular}{|l|c|}
\hline & slope \\
\hline Germany & 0,21 \\
Belgium & 0,48 \\
Austria & 0,49 \\
France & 0,55 \\
Italy & 0,77 \\
Netherlands & 0,80 \\
Portugal & 1,02 \\
Finland & 1,21 \\
Spain & 1,22 \\
Ireland & 2,07 \\
Greece & 2,18 \\
& \\
\hline
\end{tabular}

Source: Own calculations.

Figure 9 shows another aspect of this asymmetry. We present the standard deviations (across countries) of the cyclical components of GDP growth and 
observe a striking pattern. During the boom years 1999-2007 the standard deviation increases significantly. At the start of the financial crisis in 2008 the standard deviations decline but pick up again in 2011. This evidence suggests that during the boom years between 1999 and 2007 the asymmetry in the amplitude of the business cycle increased significantly until the crash, when it declined dramatically. In other words, the crash was almost as intensive again. Things changed with the sovereign debt crisis, which had the effect of introducing an increasing divergence in the amplitude of the cycle. This result is also confirmed by Allard, et al. (2013), who find that growth divergence has continued to be high and in fact increased during the second half of the 2000s.

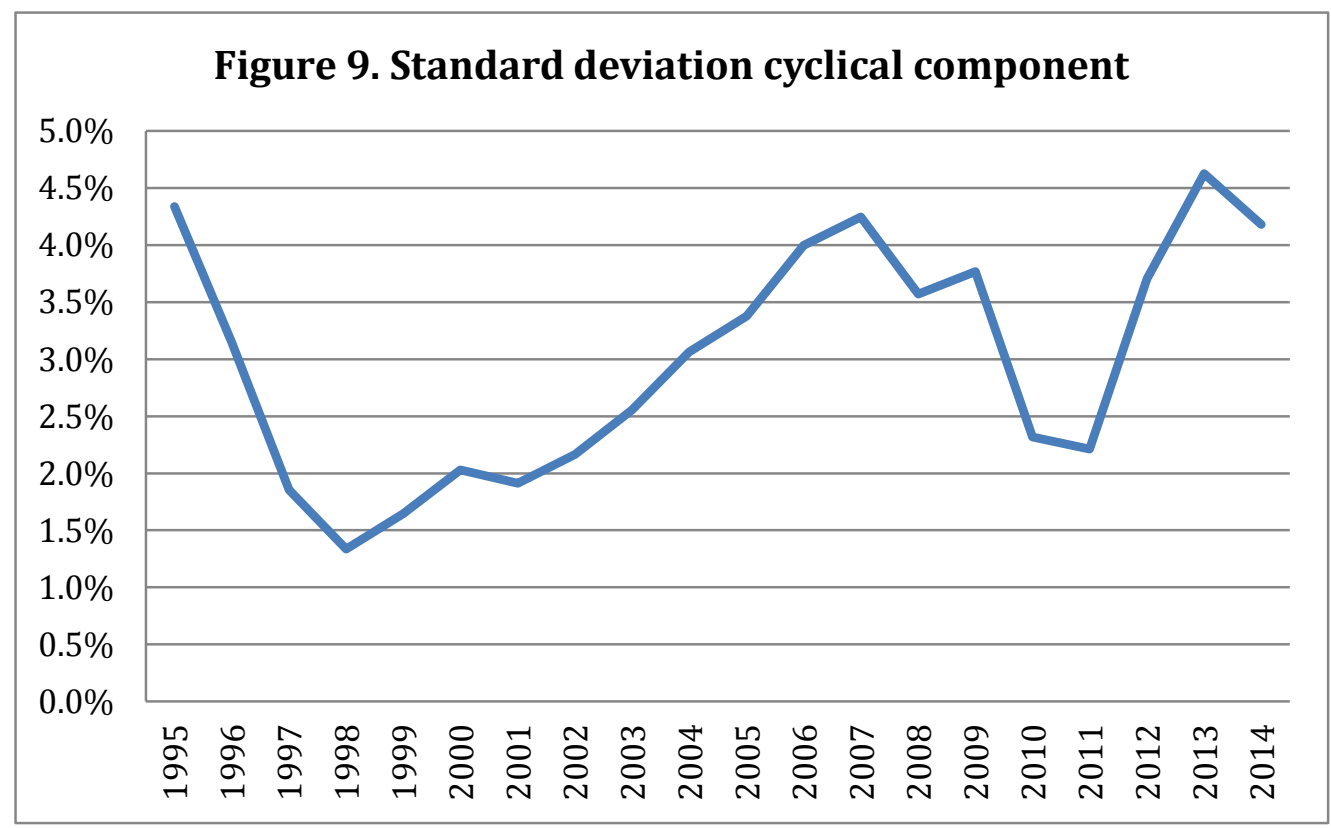

Source: Own calculation based on Eurostat.

\section{Comparison with other empirical results}

How do our results compare with other empirical studies analysing the nature of asymmetric shocks in the eurozone? The empirical research on asymmetric shocks has been very much influenced by Bayoumi and Eichengreen (1993). These authors applied the Blanchard and Quah (1989) procedure that extracts demand and supply shocks from structural VARs. This procedure is applied to every eurozone country. These national demand and supply shocks are then 
correlated with the other countries' demand and supply shocks, or with an estimate of the eurozone-wide demand and supply shocks. The latter procedure was applied by Fidrmuc and Korhonen (2002). We show their results in Table 3. It is striking to find how low the correlation coefficients are. In fact they are so low that most are not significantly different from zero.

Table 4.

\begin{tabular}{|lc|}
\hline \multicolumn{2}{|l|}{ Correlation of demand shocks } \\
\hline Austria & 0,08 \\
Belgium & 0 \\
Finland & 0,06 \\
France & 0,3 \\
Germany & 0,18 \\
Greece & $-0,01$ \\
Ireland & 0,13 \\
Italy & 0,57 \\
Netherlands & 0,04 \\
Portugal & 0,09 \\
Spain & 0,16 \\
\end{tabular}

Source: Fidrmuc and Korhonen (2002).

Such a result should not really be surprising. In the Blanchard \& Quah (1989) procedure a structural VAR is used on macroeconomic variables such as output and prices. This means that in the first step all endogenous relations between these variables is taken out. What is left over is the exogenous noise the exogenous chocks) in these variables. By introducing identifying restrictions this procedure then finally allows us to interpret part of this exogenous noise to come from aggregate demand and part from aggregate supply. This exogenous noise appears to be rather small compared to the movements generated by the endogenous dynamics of booms and busts. It is therefore not really surprising that this procedure leads to low and mostly insignificant correlations across countries.

The Bayoumi and Eichengreen (1993) approach (which is based on the Blanchard \& Quah (1989) procedure is very much influenced by the standard OCA literature. As argued earlier, the latter has focused on exogenous shocks and how these are correlated across countries. It is clear that by eliminating the 
endogenous boom and bust cycles from the statistical analysis one obtains a very shallow view on the nature of the asymmetry of shocks in the eurozone. Our procedure does not have this drawback and allows us to obtain a better view on how intensely the eurozone business cycles are connected.

To conclude this and the previous section we would like to stress two limitations of our empirical analysis. First, our analysis has been based on the first 15 years of the eurozone. This period saw massive boom-bust dynamics. The boom in a number of peripheral countries can be said to have been influenced by the start of the eurozone, which led to strong declines in the real interest rates in these countries. Surely, the future will look different. Yet, as capitalism has been a story of booms and busts, one should expect that these dynamics will come back, albeit triggered by other events.

Second, the fact that we find overwhelming evidence for the existence of temporary business cycle movements does not make the classical OCA shocks irrelevant. These will also occur regularly. The case of Finland illustrates this. This country recently experienced a classical OCA shock, necessitating an internal devaluation. When these shocks occur there will be a need for flexibility.

\section{Implications for the governance of the eurozone}

The findings reported in the previous sections put the need for stabilisation in the eurozone in a new light. We analyse two implications that involve steps towards fiscal integration.

First, the finding of the overwhelming importance of the cyclical and temporary component of output growth should lead to the conclusion that efforts to stabilise the business cycle should be strengthened relative to the efforts that have been made to impose structural reforms. In terms of our theoretical analysis this means that Figure 6 is probably the relevant one. Again, this does not mean that flexibility can be disposed of. 


\subsection{Common unemployment insurance}

A second implication of our empirical results relates to the many proposals made to create a fiscal space at the eurozone level in the form of a common unemployment insurance system (see e.g. Van Rompuy, et al.(2012), the socalled "Four Presidents report", Enderlein, et al. (2012), Beblavy, et al. (2015)). The proposals for such an insurance system have very much been influenced by the standard assumption made in the OCA-theory that shocks are asymmetric, i.e. that when one country experiences a recession, and thus increasing unemployment, the other country experiences a boom, and declining unemployment. This facilitates the workings of the common unemployment insurance system. The booming country transfers resources to the country in a recession and thereby smoothes the business cycles in the two countries. Technically and politically such a system encounters relatively few problems.

Problems may arise when, as we have found, business cycles are relatively well synchronised but of very different amplitude in the different member countries. In that case most countries will tend to experience a recession at about the same time; in some countries the recession will be mild but in others very intense. This creates both an economic and a political problem. First, countries with a mild recession are asked to transfer resources to countries experiencing a stronger recession. This tends to reduce the intensity of the recession in the latter country at the expense of making it more intense in the former country. It is not clear that this improves welfare. Second, it is likely to create important political problems in the former country that is asked to transfer resources when the economy is not doing well.

Another way to formulate the previous insights is the following. The traditional proposals for a eurozone unemployment insurance mechanism are predicated on the view that there is a need to smooth differences in unemployment changes across countries. That is, it is assumed that some countries experience increases others declines in unemployment. The insurance mechanism then smoothes these inter-country differences. We have noted, however, that this is not a typical eurozone asymmetry. What we found is that most countries are likely to experience a boom and a recession at about the same time, with different 
intensities and amplitudes. There is therefore relatively little need for intercountry smoothing of business cycle movements. The more pressing need is to smooth volatilities over time.

The previous analysis suggests that common unemployment insurance schemes should put emphasis on smoothing over time and not so much on inter-country smoothing. This can be achieved by allowing the common unemployment insurance scheme to accumulate deficits and surpluses over time. The fiscal rule that could be imposed is that the insurance scheme balances over the business cycle. Beblavy and Maselli (2014) have performed interesting simulations of several schemes that impose such a fiscal rule. In general it appears from these simulations that such an insurance mechanism can be implemented. Such a rule would make it possible to automatically balance the need for inter-country and inter-temporal smoothing.

\subsection{National stabilisation?}

In principle, inter-temporal smoothing could be done at the national level, by allowing the national budgets to do the job. However, the large differences in the amplitude of business-cycle movements makes such a purely national approach problematic, as it leads to large differences in the budget deficits and debt accumulation between countries. These differences quickly spill over into financial markets when countries that are hit very hard by a downward movement in output are subjected to sudden stops and liquidity crises (see De Grauwe (2011)). This is likely to force them to switch off the automatic stabilisers in their national budgets (De Grauwe and Ji (2012). As we argued, there this can push countries into a bad equilibrium.

Put differently, in the absence of a budgetary union, large differences in the amplitude of the business cycles are likely to hit the countries experiencing the more severe recession by "sudden stops", i.e. by large liquidity outflows that force them to abandon any ambition to stabilise the business cycle shocks. In addition, these liquidity outflows are inflows in some other countries in the 
monetary union, typically those that are least hit by the recession. ${ }^{6}$ Their economic conditions improve at the expense of the others. The stabilisation of common business shocks with different amplitudes at the national level makes the system unstable.

In this respect the research of Alcidi and Thirion (2015) is relevant. These authors find that while the core eurozone countries have been able to stabilise part (about 50\%) of the business-cycle shocks at the national level since the eruption of the debt crisis in 2010, the peripheral countries have been unable to do so, and also unable to profit from insurance mechanisms at the level of the eurozone. As a result, most (90\%) of the business-cycle shocks had to be absorbed by drops in consumption (and therefore in employment).

National stabilisation efforts do not work but introduce an element of instability into a monetary union, mainly because they leave the countries most hit by the business-cycle shocks unable to stabilise. Thus, when business-cycle shocks dominate (as we have shown in the previous section) it will be necessary to follow a common approach to the stabilisation of the business cycles. This can only be provided by a budgetary union. By centralising part of the national budgets into a common budget managed by a common political authority, the different increases in budget deficits following from a (common) recession translate into a budget deficit at the union level. As a result, the destabilising flows of liquidity between countries disappear, and the common budgetary authority can allow the automatic stabilisers in the budget to do their role in smoothing the business cycle. In fact, because a common budget also generates implicit inter-country transfers the countries with the deepest recession will profit from the automatic stabilising features of the common budget most. As a result, a common budget provided the most effective way to stabilise the business cycle.

It is clear, however, that a budgetary union in which a significant part of national taxation and spending is transferred to a European government and parliament

${ }^{6}$ This is confirmed by the empirical work of Furceri and Zdzienicka (2013) and Hoffmann and Nitschka (2012) who find that during recessions risk sharing through financial markets declines dramatically. 
is far off. It cannot, therefore, be invoked today to solve the lack of stabilisation at the European level.

In addition, the common insurance mechanisms now being proposed (see Beblavy and Maselli (2014)) have a relatively small inter-temporal smoothing component, amounting to no more than $0.1 \%$ to $0.2 \%$ of GDP over the business cycle, certainly insufficient to produce a significant inter-temporal smoothing at the EU-level. Fortunately, there are possibilities to enhance stabilisation at the eurozone level that do not require a full budgetary union.

\subsection{A stabilisation fund}

Here is a scheme that can provide some stabilisation at the eurozone level. A stabilisation fund would be set up. This could in fact be the existing European Stability Mechanism (ESM). During recessions, the ESM would buy national government bonds and issue an equivalent amount of ESM-bonds (Eurobonds) backed by the participating member-countries. During booms the EMS would do the opposite, i.e. buy back the ESM-bonds and sell the national bonds into the bond markets. In doing so, there would be no net accumulation of ESM-bonds over the business cycle.

How does this scheme contribute to stabilisation at the eurozone level? During recessions national budget deficits increase automatically. Put differently, national governments have to issue new government bonds. We have argued that this process is likely to lead to destabilising capital flows, as some countries' recessions are deeper than others. This leads to more bond issues in the countries hit by the deepest recessions than in the countries experiencing mild recessions. The bond-buying operations by the ESM would then tend to support the government bond markets in the eurozone in general, but at the same time the support would be strongest in the government bond markets of the countries experiencing the deepest recessions. As a result, the EMS-buying operations would tend to unify the government bond markets and would reduce the scope 
for destabilising capital flows within the eurozone. This would be a significant achievement. $^{7}$

There are many technical issues to be solved here. In particular, in order to avoid a net accumulation of EMS-bonds over the business cycle, the EMS would only be allowed to buy bonds corresponding to the cyclical component of the government budget. This makes the computation of reliable structural government balances imperative.

\section{EMU and long-term growth}

We argued that there are too few institutions in the eurozone to perform the necessary stabilisation responsibilities of a monetary union. It is clear from our previous analysis that there is also a long-term growth problem in the eurozone. This is made obvious in Table 5. This shows the estimated long-term growth rates in 1995 and in 2014 in the eurozone countries. These are obtained from the same Hodrick-Prescott procedure used in the previous sections. We observe that there has been a significant decline of the trend growth in all countries. Note that this has been observed in most developed countries (see Summers (2014) and Teugels and Baldwin(2014)).

Conventional policy-maker wisdom in the EU is that the low and declining longterm growth in the eurozone is due to a lack of flexibility in product and labour markets. As a result of this wisdom, countries have been pushed towards introducing structural reform programmes. We showed the evidence in Figures 1 and 2. Yet all the enthusiasm for introducing flexibility in product and labour markets has borne little fruit in terms of boosting economic growth in the eurozone. In fact, declining long-term economic growth has been correlated with increasing flexibility. In Appendix II we present an econometric analysis of the relation between long-term economic growth and flexibility of labour and

\footnotetext{
7 The proposed stabilisation fund resembles the proposal made by Drèze and Durré (2012). The Drèze \& Durré proposal, however, is a pure inter-country insurance mechanism insisting that the fund balance its books at each moment in time. Note also that the scheme proposed here is very different from the OMTprogramme of the ECB that is intended to be used in times of crisis. In addition, OMT is conditional on austerity programmes and tends to be procyclical.
} 
product markets. We conclude from that analysis that the evidence of a positive correlation between growth and flexibility is weak (see also IMF (2015)).

Table 5. Estimates of long-term growth rates in eurozone in 1995 and 2014

\begin{tabular}{|l|rrr|}
\hline & $\begin{array}{c}\text { Trend } \\
1995\end{array}$ & $\begin{array}{l}\text { Trend } \\
2014\end{array}$ & Change \\
\hline Austria & $2,05 \%$ & $1,62 \%$ & $-0,42 \%$ \\
Belgium & $1,95 \%$ & $1,52 \%$ & $-0,43 \%$ \\
Finland & $2,76 \%$ & $1,64 \%$ & $-1,12 \%$ \\
France & $1,84 \%$ & $1,32 \%$ & $-0,52 \%$ \\
Germany & $1,31 \%$ & $1,20 \%$ & $-0,12 \%$ \\
Greece & $2,19 \%$ & $0,10 \%$ & $-2,09 \%$ \\
Ireland & $4,74 \%$ & $2,71 \%$ & $-2,03 \%$ \\
Italy & $0,87 \%$ & $0,15 \%$ & $-0,72 \%$ \\
Netherlands & $2,17 \%$ & $1,42 \%$ & $-0,75 \%$ \\
Portugal & $1,50 \%$ & $0,47 \%$ & $-1,03 \%$ \\
Spain & $2,81 \%$ & $1,65 \%$ & $-1,15 \%$ \\
& & & \\
\hline
\end{tabular}

Source: Calculations based on Eurostat.

\section{Conclusion}

Since the sovereign debt crisis in the eurozone, member countries have been pushed towards introducing more flexibility into labour and product markets. This drive towards structural reforms was very much influenced by the traditional theory of optimal currency areas (OCA). This theory stresses that in the face of asymmetric shocks member countries should have a sufficient degree of labour and product market flexibility to adjust to these shocks. Without such flexibility adjustment will be impossible, thereby undermining the sustainability of the monetary union.

The underlying assumption of the OCA prescription for structural reform is that asymmetric shocks are permanent (e.g. permanent changes in preferences or productivity shocks). When the shocks are temporary it does not follow that more flexibility is the answer. More specifically, when the shocks are the result of unsynchronised business cycle movements, the way to deal with them is by stabilisation efforts. 
In this paper we have provided empirical evidence to suggest that the most significant shocks in the eurozone have been the result of boom and bust, driven by waves of optimism and pessimism. These business-cycle movements have been relatively well-synchronised. What was not synchronised was the amplitude of these business-cycle movements, where some countries experienced much greater amplitude in business cycles than others.

In principle, these business-cycle movements could be stabilised at the national level without the need for budgetary union. However, as the amplitude of these movements is so different, countries experiencing the deepest recession are likely to be hit by 'sudden stops', i.e. liquidity outflows triggered by fear and panic, which forces them to switch off the automatic stabilisers in the budget, preventing them from conducting any stabilisation.

We argued that the best possible way to deal with the business-cycle movements whose amplitude is unsynchronised is by introducing a budgetary union. By centralising part of the national budgets into a common budget managed by a common political authority, the various increases in budget deficits following from a (common) recession translate into a budget deficit at the union level. As a result, the destabilising flows of liquidity between countries during the recession disappear, and the common budgetary authority can allow the automatic stabiliser in the common budget to perform its role in smoothing the business cycle.

It is highly unlikely that the governance of the eurozone will move in the direction of creating institutions capable of providing the necessary stabilisation of booms and busts that national governments are no longer able to provide. The willingness to move in this direction is minimal. Thus, one has to look for schemes that introduce some stabilisation at the eurozone level without going all the way towards budgetary union.

We discussed two schemes that have a potential for stabilisation at the eurozone level. One is a common unemployment insurance scheme that puts more emphasis on inter-temporal insurance and less on inter-country insurance. The second scheme consists of using the ESM as a stabiliser of national government bond markets. It would buy national government bonds and issue ESM bonds 
during recession and do the opposite during an economic boom, making sure that over the business cycle there would be no net issue of ESM bonds. We argued that this would make it possible to stabilise the government bond markets during a recession, thereby avoiding a destabilisation of capital flows within the eurozone.

We also argued that the new governance of the eurozone that is based on imposing structural reforms does not solve the stabilisation problem that arises from the fact that most asymmetric shocks in the eurozone originate in booms and busts in economic activity.

This new governance focus on structural reforms is also unlikely to boost longterm growth. As we have shown in this paper, structural reforms have an negligible effect on long-term growth. The paradox is that the austerity programmes followed in the eurozone have reduced public investment dramatically and have thereby eliminated one of the most important channels to long-term economic growth. 


\section{References}

Allard, C., Koeva Brooks, P., Bluedorn, J., Bornhorst, F., Kritstopherson, K., Ohnsorge, F., Poghosyan, T. (2013), Toward a Fiscal Union for the Euro Area, IMF Staff Discussion Note (www.imf.org/external/pubs/ft/sdn/2013/sdn1309.pdf).

Acemoglu, D., (2009), Introduction to Modern Economic Growth, Princeton University Press.

Acemoglu, D., and Robinson, J., (2012), Why Nations Fail: The Origins of Power, Prosperity, and Poverty, Crown Business.

Alcidi, C. and G. Thirion (2015), "Feasibility and Added Value of a European Unemployment Benefit Scheme", Interim Report, CEPS, Brussels.

Ball, L. M. (2009), "Hysteresis in Unemployment: Old and New Evidence", US National Bureau of Economic Research (NBER), Working Paper No. 14818.

Barro, R. and X. Sala-i-Martin (2003), Economic Growth, MIT Press, Cambridge, Massachusetts.

Bayoumi, T. and B. Eichengreen (1993), "Shocking Aspects of European Monetary Integration", in Torres, F. and F. Giavazzi (eds), Growth and Adjustment in the European Union, pp. 193-230, Cambridge University Press, Oxford.

Blanchard, O. J. and H. L. Summers (1986), "Hysteresis and the European Unemployment Problem", NBER Macroeconomics Annual 1: 15-78. doi:10.2307/3585159

Blanchard, O. and D. Quah (1989), The Dynamic Effect of Demand and Supply Disturbances, American Economic Review, 79, pp. 655-673.

Beblavy, M., Marconi, G. and I. Maselli (2015), European Unemployment Benefits Scheme: The rationale and the challenges ahead, CEPS Special Report, Centre for European Policy Studies, September.

Beblavy, M. and I. Maselli (2014), An Unemployment Insurance Scheme for the Euro Area: A simulation exercise of two options, CEPS Special Report, no98, Centre for European Policy Studies.

De Grauwe, P., and Ji, Y., (2015), Crisis Management and Economic Growth in the Eurozone, Paper prepared for the conference on "Economic Growth in Europe" at the Bank of Portugal, Lisbon, May.

De Grauwe, P. (2014), Economics of Monetary Union, Oxford University Press, 10th edition, Oxford.

De Grauwe, P. and Y. Ji (2012), Self-fulfilling crises in the Eurozone: an empirical test, Journal of International Money and Finance, Volume 34, April, pp. 15-36.

De Grauwe, P. (2011), The Governance of a Fragile Eurozone, CEPS Working Documents, Economic Policy, May (http://www.ceps.eu/book/governancefragile-eurozone).

Drèze, J. and A. Durré (2012), "Fiscal Integration and Growth Stimulation in Europe", CORE Discussion Papers, CORE, Louvain-la-Neuve. 
Enderlein, H., et al. (2012), Completing the Euro. A road map towards fiscal union in Europe, Report of the "Tomaso Padoa-Schioppa Group", Notre Europe, June.

European Central Bank (2015), Progress with structural reforms across the euro area and their possible impacts, Economic Bulletin, Issue 2.

Fatas, A. and L. Summers (2015), The Permanent Effects of Fiscal Consolidations, unpublished paper.

Fidrmuc, J. and I. Korhonen (2002), Similarity between supply and demand shocks between the Euro Area and the CEECs, in Monetary Policy and Currency Competition in Emerging Markets, Croatian National Bank.

Furceri, D. and M.A. Zdzienicka (2013), "The Euro Area Crisis: Need for a

Supranational Fiscal Risk Sharing Mechanism?”, IMF Staff Discussion Note No. 13198, International Monetary Fund, Washington, D.C., September.

Hoffmann, M. and T. Nitschka (2012), "Securitization of mortgage debt, domestic lending, and international risk sharing", Canadian Journal of Economics, 45(2), pp. 493-508.

IMF World Economic Outlook (2015), Ch. 3, Box 3.5 on The Effects of Structural Reforms on Total Factor Productivity, pp. 104-107.

Kindleberger, C. (2001), Manias, Panics and Crashes. A History of Financial Crises, Wiley Investment Classics, John Wiley \& Sons, 4th Edition, 304 pp.

Minsky, H. (1986), Stabilizing and Unstable Economy, Yale University Press.

Sapir, A. (2015), Architecture reform for an heterogeneous EMU: National vs. European institutions, Paper presented at the Conference organized by the Bank of Portugal, "Adjustment in European Economies in the Wake of the Economic Crisis" Lisbon, 9 May.

Summers, L. (2014), Reflections on the New "Secular Stagnation Hypothesis", VoxEU, October (www.voxeu.org/article/larry-summers-secular-stagnation).

Teulings, C. and R. Baldwin (2014), Secular Stagnation. Facts, Causes and Cures. A new vox ebook, October (www.voxeu.org/article/secular-stagnation-factscauses-and-cures-new-vox-ebook).

Van Rompuy, H. in close collaboration with Barroso, J.M., Juncker, J.C., Draghi, M. (2012), "Towards a Genuine Economic and Monetary Union", European Council, 5 December, Final Report, ("The Four Presidents Report"). 


\section{APPENDIX 1}

As suggested in the main text, the choice of the smoothing parameter (lamda) in the Hodrick-Prescott (HP) filter has a significant influence on the estimate of the cyclical and permanent components of GDP-growth. In this appendix we illustrate this by comparing estimates, using a high and a low lamda. The high lamda is the same as the one used in the text and was set equal to 1200; the low lamda was set equal to 100 . We compare the results in Figure A1. It is immediately evident that in the low lamda estimates the long-term growth line follows the observed output growth line more closely. As a result, the cyclical component is on average smaller than in the high lamda case. This is made clear in Table A1, which shows the mean absolute changes in the trend and cyclical components. Even in the case of a low lamda we find that the peripheral countries have been subjected to larger cyclical than permanent movements in output.

Table A2 presents the correlation coefficients of the cyclical components of GDP growth for low lamda. It should be compared with Table 2 in the text. We observe that in the low lamda estimates the correlation coefficients are of a similar order of magnitude as in the high lamda case. Thus, one of our main conclusions, i.e. that business cycles have been highly correlated, is maintained. This is also made clear in Figure A2 that shows the evolution of the business cycle component in the two estimates. Obviously, in the low lamda estimate the business cycle components are generally lower than in the high lamda estimate. In both cases, though, we observe similarly correlated booms and busts in the eurozone. And, as Figure A3 indicates, the divergence in the amplitude of the business cycles across countries tends to increase during the boom years prior to the crisis. This is also what we found using estimates with a high lamda. Thus, one of our major empirical conclusions still stands, even when one uses a low lamda. This is that the asymmetry in the business cycles of the eurozone countries is to be found in the divergence in the amplitude of the business cycle. The business cycles themselves tended to be highly correlated.

There is reason to believe that the low lamda estimates bias the business cycle components downwards and thus the long-term growth component upwards (in 
absolute value). This is made clear from Table A3, which compares the estimates of long-term growth in 1995 and 2014 in the two lamda scenarios. We find that in the low lamda estimates the decline in long-term growth in a number of periphery countries is implausibly high. In the cases of Ireland and Greece longterm growth declines by more than 7 percentage points. (The corresponding declines in the high lamda case is $2 \%$.) 
Figure A1. Observed and trend growth of GDP

\section{High lamda(Figure 7)}
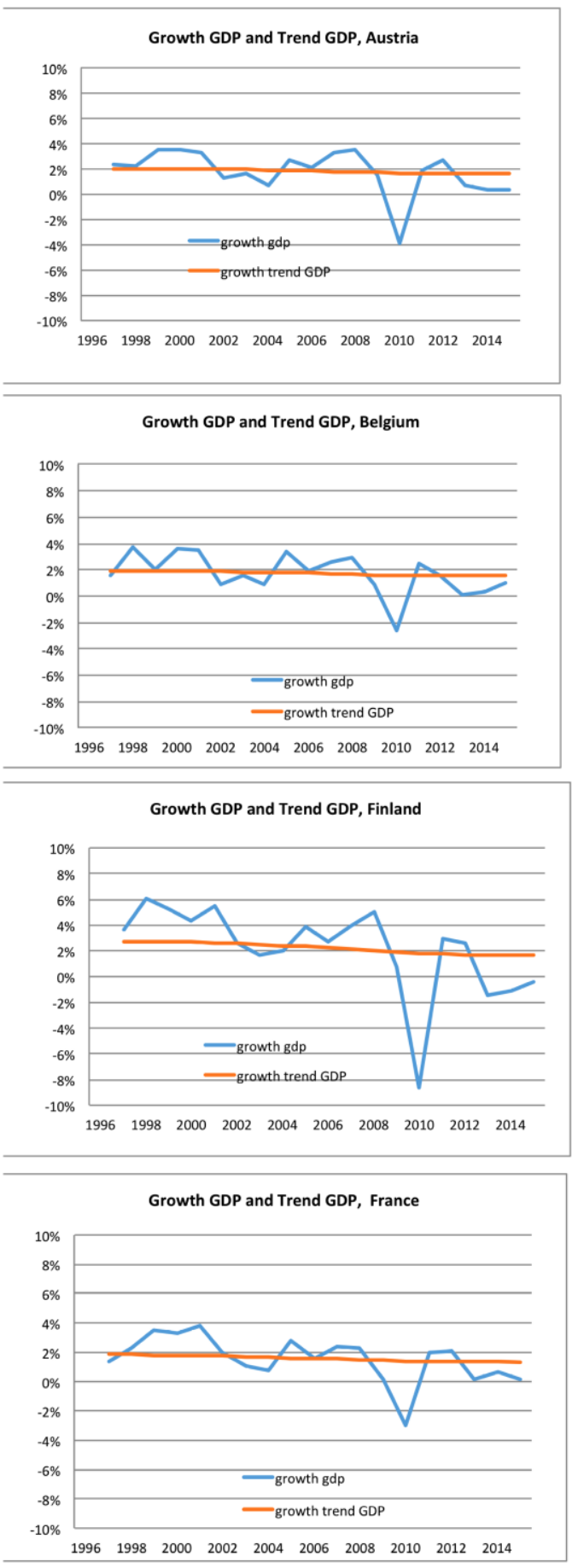

\section{Low Lamda}
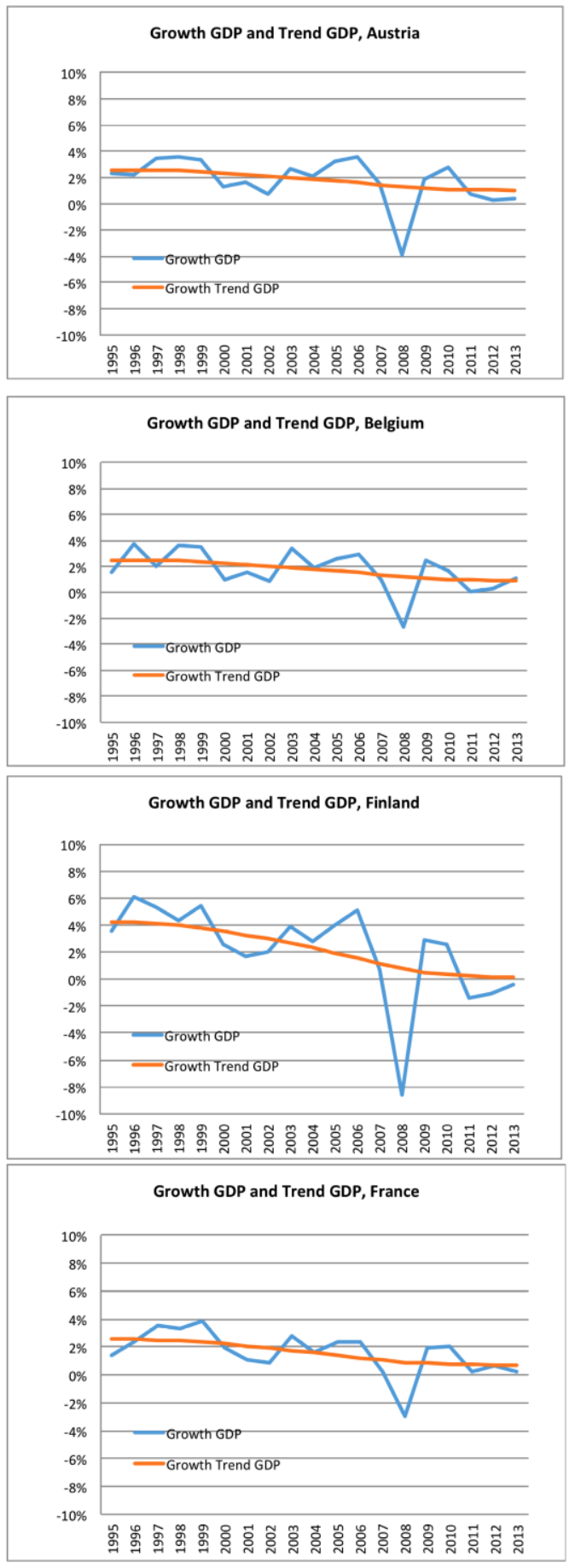
High lamda

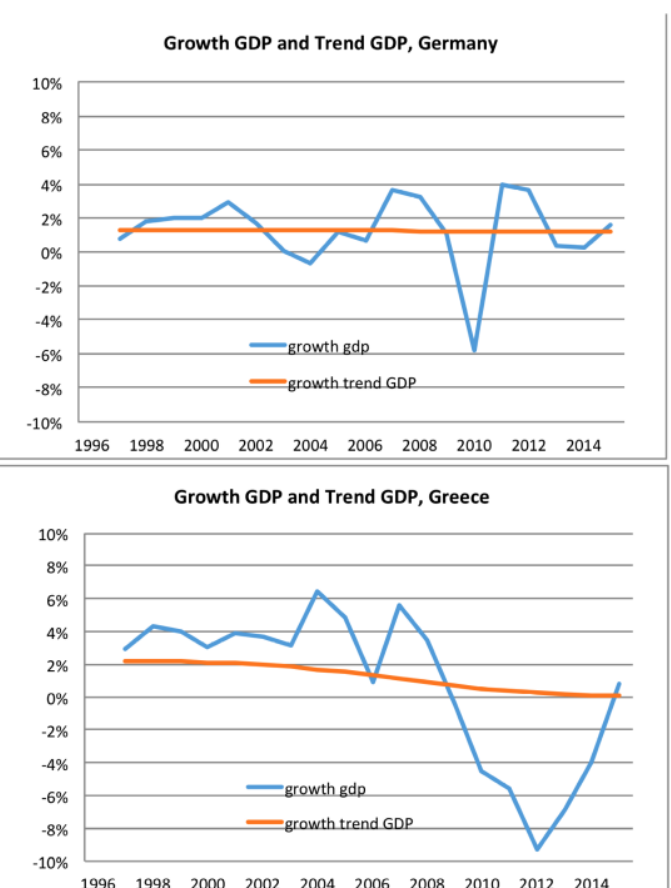

$\begin{array}{llllllllll}1996 & 1998 & 2000 & 2002 & 2004 & 2006 & 2008 & 2010 & 2012 & 2014\end{array}$
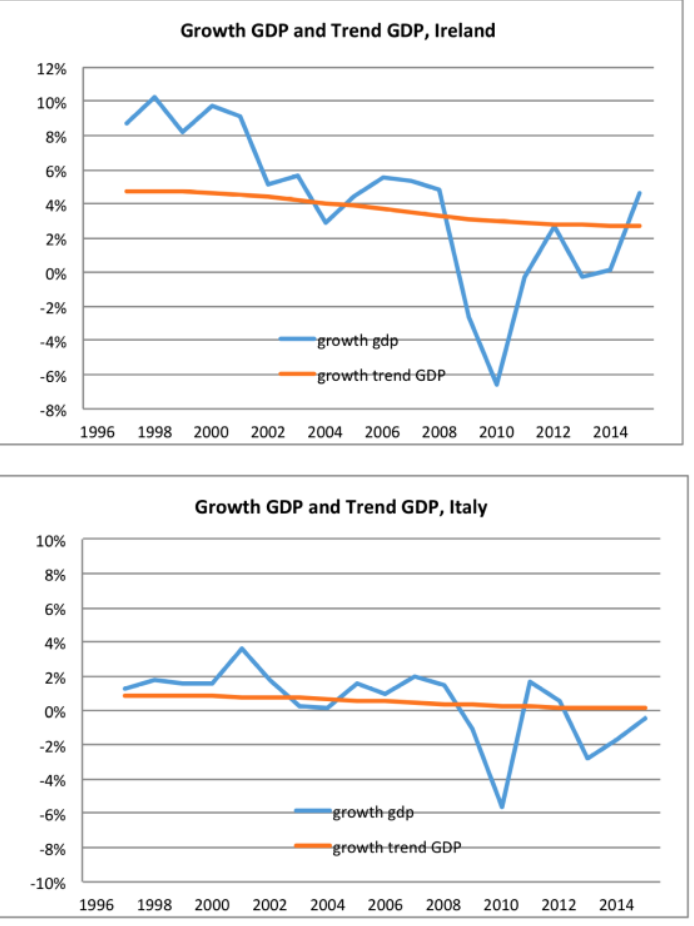

Low Lamda
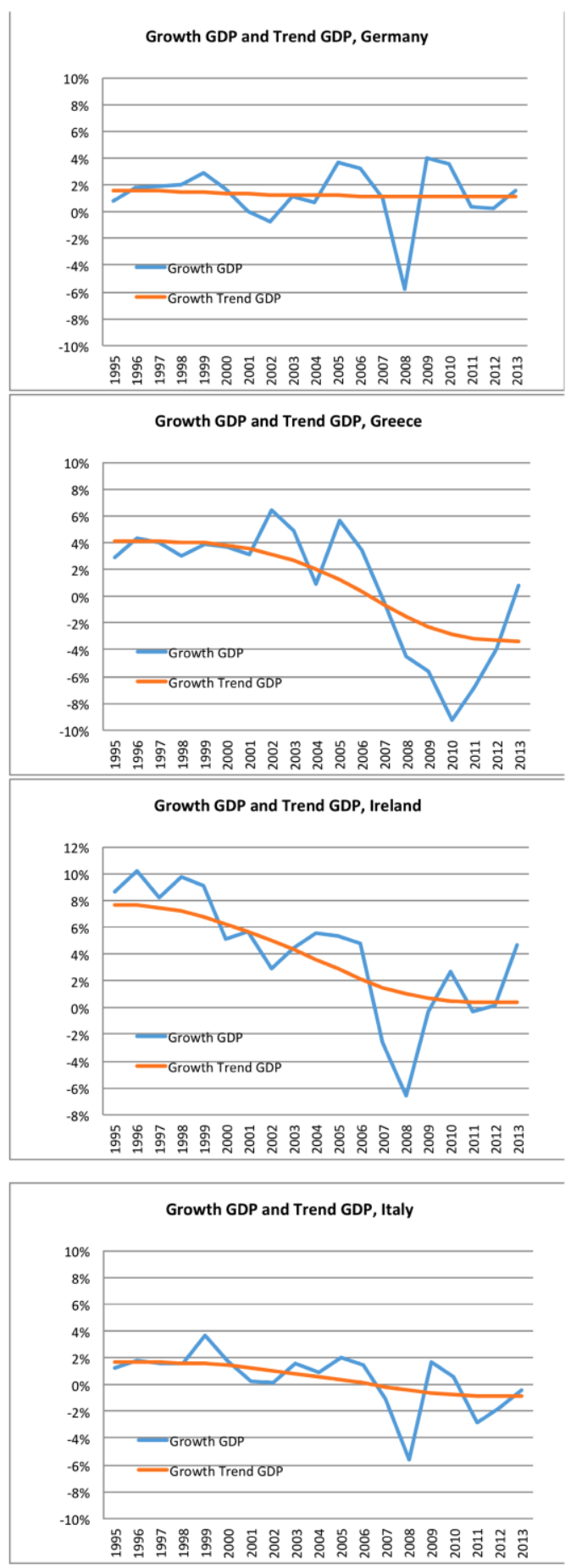
High lamda
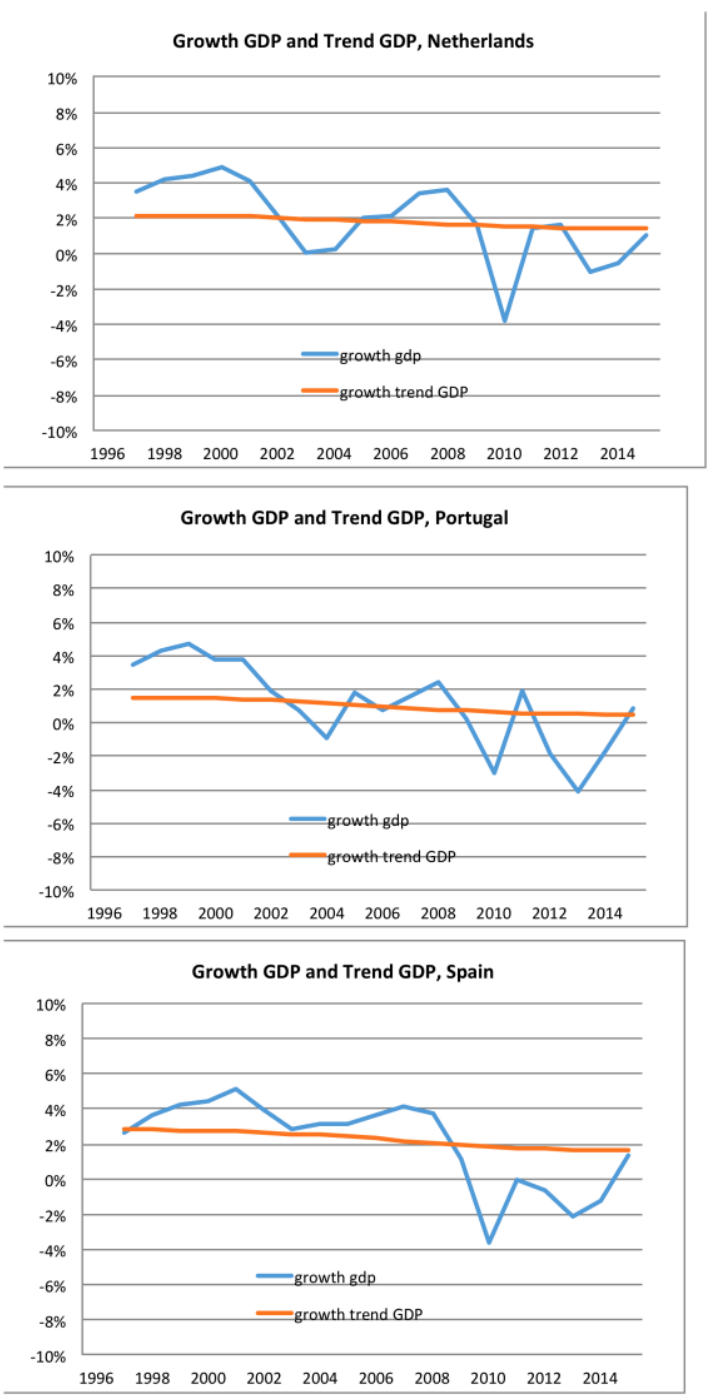

Low Lamda
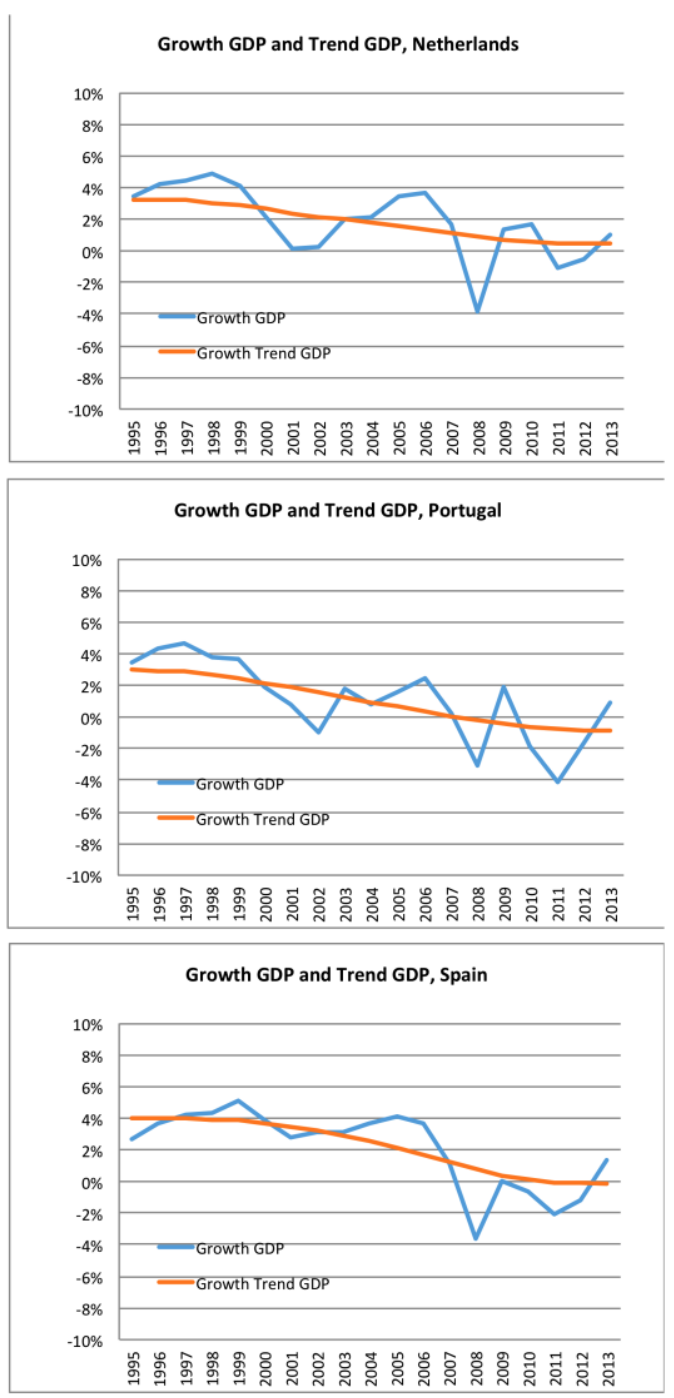
Table A1

Low lamda

\begin{tabular}{|l|ccc|}
\hline & $\begin{array}{c}\text { Mean } \\
\text { cycle }\end{array}$ & $\begin{array}{c}\text { Mean } \\
\text { trend }\end{array}$ & ratio \\
\hline Belgium & $0,97 \%$ & $1,47 \%$ & 0,66 \\
Austria & $1,18 \%$ & $1,58 \%$ & 0,75 \\
Spain & $1,69 \%$ & $2,22 \%$ & 0,76 \\
France & $1,04 \%$ & $1,27 \%$ & 0,82 \\
Portugal & $1,63 \%$ & $1,40 \%$ & 1,16 \\
Netherlands & $1,61 \%$ & $1,33 \%$ & 1,21 \\
Germany & $1,49 \%$ & $1,18 \%$ & 1,27 \\
Ireland & $3,26 \%$ & $2,48 \%$ & 1,31 \\
Finland & $2,08 \%$ & $1,53 \%$ & 1,36 \\
Italy & $1,37 \%$ & $0,96 \%$ & 1,42 \\
Greece & $4,50 \%$ & $2,85 \%$ & 1,58 \\
& & & \\
\hline
\end{tabular}

High lamda (Table 1)
\begin{tabular}{|l|rrr|}
\hline & $\begin{array}{l}\text { Mean } \\
\text { cycle }\end{array}$ & $\begin{array}{c}\text { Mean } \\
\text { trend }\end{array}$ & ratio \\
\hline Austria & $1,79 \%$ & $1,77 \%$ & 1,01 \\
Belgium & $1,72 \%$ & $1,67 \%$ & 1,03 \\
Germany & $1,55 \%$ & $1,23 \%$ & 1,26 \\
France & $2,15 \%$ & $1,49 \%$ & 1,44 \\
Netherlands & $2,66 \%$ & $1,66 \%$ & 1,60 \\
Finland & $4,35 \%$ & $2,02 \%$ & 2,15 \\
Spain & $4,58 \%$ & $2,07 \%$ & 2,21 \\
Ireland & $8,01 \%$ & $3,35 \%$ & 2,39 \\
Portugal & $3,67 \%$ & $0,81 \%$ & 4,53 \\
Italy & $2,86 \%$ & $0,41 \%$ & 7,05 \\
Greece & $9,09 \%$ & $0,90 \%$ & 10,11 \\
\hline
\end{tabular}

Table A2. Correlation coefficients of business components of GDP growth Low lamda

\begin{tabular}{|c|c|c|c|c|c|c|c|c|c|c|}
\hline Austria & Austria & Belgium & Finland & France & Germany & Greece & Ireland & Italy & Netherl & Port \\
\hline Belgium & 0,95 & & & & & & & & & \\
\hline Finland & 0,96 & 0,96 & & & & & & & & \\
\hline France & 0,91 & 0,91 & 0,93 & & & & & & & \\
\hline Germany & 0,86 & 0,77 & 0,79 & 0,84 & & & & & & \\
\hline Greece & 0,37 & 0,48 & 0,51 & 0,27 & $-0,01$ & & & & & \\
\hline Ireland & 0,73 & 0,75 & 0,79 & 0,85 & 0,59 & 0,45 & & & & \\
\hline Italy & 0,84 & 0,89 & 0,94 & 0,90 & 0,74 & 0,53 & 0,78 & & & \\
\hline Netherlands & 0,88 & 0,86 & 0,84 & 0,79 & 0,78 & 0,36 & 0,64 & 0,74 & & \\
\hline Portugal & 0,92 & 0,71 & 0,65 & 0,58 & 0,51 & 0,46 & 0,50 & 0,65 & 0,85 & \\
\hline Spain & 0,68 & 0,75 & 0,79 & 0,62 & 0,37 & 0,90 & 0,70 & 0,82 & 0,64 & 0,65 \\
\hline
\end{tabular}


Figure A2

Low lamda

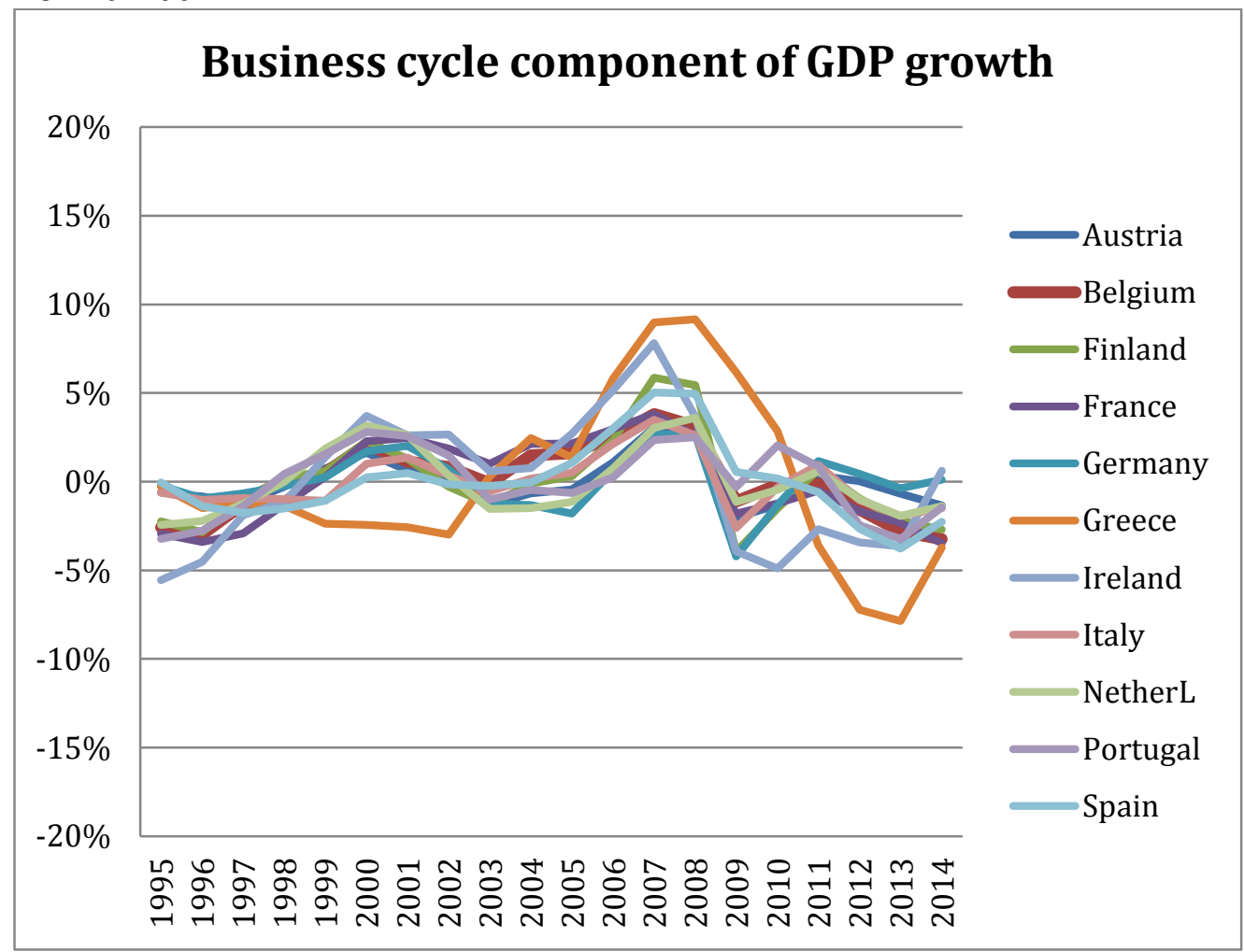

High lamda (Figure 8)

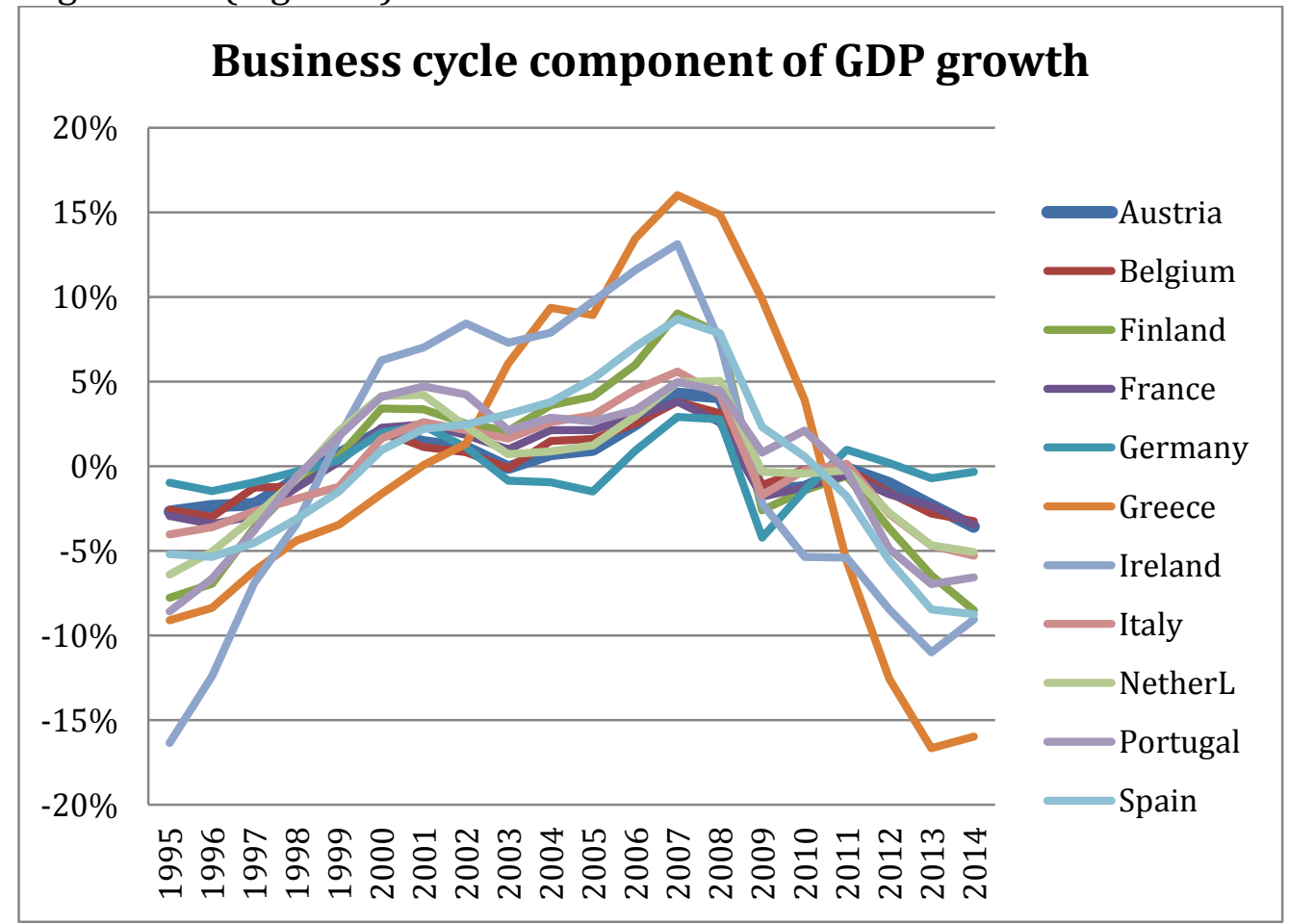


Figure A3

Low lamda

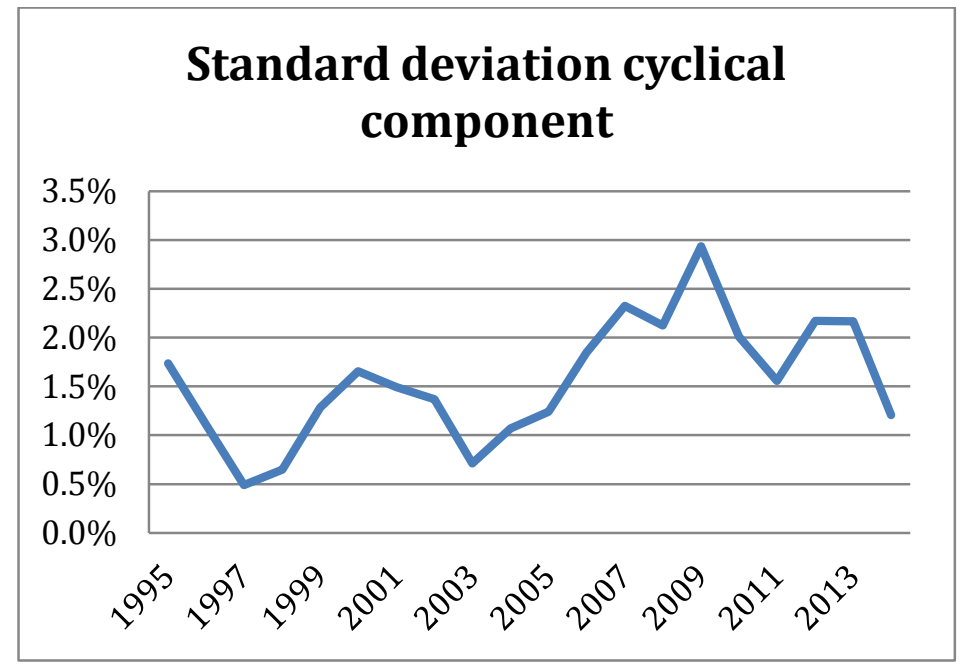

Table A3. Estimates of long term growth in 1995 and 2014 Low lamda

\begin{tabular}{|l|rrr|}
\hline & \multicolumn{1}{|c|}{$\begin{array}{l}\text { Trend } \\
1995\end{array}$} & $\begin{array}{l}\text { Trend } \\
2014\end{array}$ & Change \\
\hline Austria & $2,58 \%$ & $1,02 \%$ & $-1,56 \%$ \\
Belgium & $2,49 \%$ & $0,90 \%$ & $-1,59 \%$ \\
Finland & $4,20 \%$ & $0,09 \%$ & $-4,11 \%$ \\
France & $2,53 \%$ & $0,69 \%$ & $-1,84 \%$ \\
Germany & $1,55 \%$ & $1,11 \%$ & $-0,43 \%$ \\
Greece & $4,12 \%$ & $-3,37 \%$ & $-7,49 \%$ \\
Ireland & $7,66 \%$ & $0,41 \%$ & $-7,26 \%$ \\
Italy & $1,71 \%$ & $-0,86 \%$ & $-2,57 \%$ \\
Netherlands & $3,27 \%$ & $0,45 \%$ & $-2,83 \%$ \\
Portugal & $2,98 \%$ & $-0,87 \%$ & $-3,85 \%$ \\
Spain & $3,99 \%$ & $-0,14 \%$ & $-4,13 \%$ \\
& & & \\
\hline
\end{tabular}

High lamda (Table 5)

\begin{tabular}{|l|rrr|}
\hline & $\begin{array}{c}\text { Trend } \\
1995\end{array}$ & $\begin{array}{l}\text { Trend } \\
2014\end{array}$ & Change \\
\hline Austria & $2,05 \%$ & $1,62 \%$ & $-0,42 \%$ \\
Belgium & $1,95 \%$ & $1,52 \%$ & $-0,43 \%$ \\
Finland & $2,76 \%$ & $1,64 \%$ & $-1,12 \%$ \\
France & $1,84 \%$ & $1,32 \%$ & $-0,52 \%$ \\
Germany & $1,31 \%$ & $1,20 \%$ & $-0,12 \%$ \\
Greece & $2,19 \%$ & $0,10 \%$ & $-2,09 \%$ \\
Ireland & $4,74 \%$ & $2,71 \%$ & $-2,03 \%$ \\
Italy & $0,87 \%$ & $0,15 \%$ & $-0,72 \%$ \\
Netherlands & $2,17 \%$ & $1,42 \%$ & $-0,75 \%$ \\
Portugal & $1,50 \%$ & $0,47 \%$ & $-1,03 \%$ \\
Spain & $2,81 \%$ & $1,65 \%$ & $-1,15 \%$ \\
& & & \\
\hline
\end{tabular}




\section{APPENDIX 2 \\ Econometric analysis of the relation between growth and flexibility}

In order to find out how labour and product market flexibility affect economic growth, we performed an econometric analysis identifying the variables that can affect economic growth. The traditional theory of economic growth has identified a number of fundamental variables that drive the economic growth process. These variables are population growth, physical and human capital accumulation and technological progress (the residual in Solow's growth model). Recent theoretical contributions have highlighted the importance of institutions as deep variables that influence the process of capital accumulation and technological progress (productivity growth). Influential contributions are Barro and Sala-i-Martin (2003), Acemoglu and Robinson (2012).

There are many institutional features that can influence the economic growth process. The econometric literature has put a lot of emphasis on political institutions (nature of democracy, transparency of political system, rule of law, etc.) that affect the dynamics of physical and human capital accumulation and technological progress, and through this channel economic growth. The flexibility of labour and capital markets (or the lack thereof) is part of the institutional characteristics of countries that can affect economic growth.

In this section we present the results of estimating an econometric growth model using indicators of the degree of flexibility in labour and product markets (as measured by the OECD) as one of the institutions that can facilitate capital accumulation and productivity growth. The analysis is based on De Grauwe and Ji (2015).

The study is limited in that it focuses on flexibility in labour and product markets and not the many other institutions that have been identified in the econometric growth literature (see Barro and Sala-i-Martin (2003) and Acemoglu (2009)). One institutional feature we introduce in the analysis is the quality of public governance. We use the World Bank's index of government effectiveness. Our study is limited in another sense. We restrict our econometric analysis to OECD countries. The main reason is that the indices of labour and output market 
flexibility that we are interested in have been constructed by the OECD for the OECD-member countries.

One must also take into account that reverse causality may be at work and bias the results. This reverse causality runs as follows. In countries with high growth, there is a high demand for labour protection. Workers and their representatives are strong and are pushing for legislation to provide strong employment protection. As a result, we will observe that high growth is correlated with a lot of employment protection. This is in fact what we find when applying an OLS estimator in a model explaining growth by employment protection (see De Grauwe and Ji (2015)).

In order to correct for this reverse causality, we used an instrumental variable method. We selected two instruments. One is the lagged index of employment protection (EPL), the other is the ideological composition of the government along the scale right to left. This takes the view that employment protection is positively correlated with the ideological composition of governments, i.e. more leftist governments push for more employment protection. The results of this instrumental variable estimation are presented in Table 4.

We find that investment in physical and human capital has the expected positive and significant effects on economic growth. Employment protection and product market regulations do not have a significant effect on economic growth. Note that similar results were found recently by IMF (2015). By contrast, the World Bank index of government effectiveness has a significantly positive effect on economic growth, while government consumption (as a \% of GDP) negatively affects economic growth.

We conclude that the mainstream policy view that flexibility in labour and production is important to boost economic growth is not based on strong empirical evidence. The paradox is that the austerity programmes followed in the eurozone have reduced public investment dramatically and thereby have eliminated one of the most important channels that lead to long-term economic growth. 
Table A4. Estimation of economic growth as a function of variables in first column

\begin{tabular}{|c|c|c|c|c|c|}
\hline & $\begin{array}{c}(1) \\
\text { Advanced } \\
\text { economies } \\
\text { 1985-2013 } \\
\end{array}$ & $\begin{array}{c}\text { (2) } \\
\text { OECD } \\
\text { economies } \\
1998-2013 \\
\end{array}$ & $\begin{array}{c}\text { (3) } \\
\text { OECD } \\
\text { economies } \\
1998-2013 \\
\end{array}$ & $\begin{array}{c}\text { (5) } \\
\text { Advanced } \\
\text { economies } \\
1998-2013 \\
\end{array}$ & $\begin{array}{c}\text { (6) } \\
\text { Advanced } \\
\text { economies } \\
\text { 1998-2013 } \\
\end{array}$ \\
\hline \multicolumn{6}{|l|}{ Second Stage: } \\
\hline Investment GDP ratio & $\begin{array}{c}0.111 \\
(0.091)\end{array}$ & $\begin{array}{l}0.270 * * \\
(0.129)\end{array}$ & $\begin{array}{l}0.339 * * \\
(0.140)\end{array}$ & $\begin{array}{l}0.192 * * \\
(0.095)\end{array}$ & $\begin{array}{l}0.257 * * \\
(0.118)\end{array}$ \\
\hline $\begin{array}{l}\text { Tertiary education/total } \\
\text { population }\end{array}$ & $\begin{array}{c}1.798 * * * \\
(0.148)\end{array}$ & $\begin{array}{c}1.492 * * * \\
(0.160)\end{array}$ & $\begin{array}{c}1.464 * * * \\
(0.138)\end{array}$ & $\begin{array}{c}1.456 * * * \\
(0.147)\end{array}$ & $\begin{array}{c}1.429 * * * \\
(0.127)\end{array}$ \\
\hline Real effective exchange rate & $\begin{array}{c}-0.041 * * * \\
(0.011)\end{array}$ & $\begin{array}{c}-0.039 * * * \\
(0.013)\end{array}$ & $\begin{array}{c}-0.050 * * * \\
(0.015)\end{array}$ & $\begin{array}{c}-0.040 * * * \\
(0.012)\end{array}$ & $\begin{array}{c}-0.052 * * * \\
(0.015)\end{array}$ \\
\hline Working population growth & $\begin{array}{l}-0.425 \\
(0.331)\end{array}$ & $\begin{array}{c}-0.776 * * * \\
(0.299)\end{array}$ & $\begin{array}{c}-0.901 * * * \\
(0.311)\end{array}$ & $\begin{array}{c}-0.658 * * \\
(0.274)\end{array}$ & $\begin{array}{c}-0.792 * * * \\
(0.290)\end{array}$ \\
\hline $\begin{array}{l}\text { Government consumption } \\
\text { GDP ratio }\end{array}$ & $\begin{array}{c}-0.670 * * * \\
(0.148)\end{array}$ & $\begin{array}{c}-0.597^{* * * *} \\
(0.180)\end{array}$ & $\begin{array}{c}-0.535^{* * *} \\
(0.165)\end{array}$ & $\begin{array}{c}-0.733^{* * *} \\
(0.174)\end{array}$ & $\begin{array}{c}-0.666 * * * \\
(0.154)\end{array}$ \\
\hline Real retirement age & $\begin{array}{c}0.170 \\
(0.148)\end{array}$ & $\begin{array}{c}0.080 \\
(0.192)\end{array}$ & $\begin{array}{c}0.085 \\
(0.189)\end{array}$ & $\begin{array}{c}0.192 \\
(0.175)\end{array}$ & $\begin{array}{c}0.189 \\
(0.173)\end{array}$ \\
\hline Government effectiveness & $\begin{array}{c}0.737 \\
(1.019)\end{array}$ & $\begin{array}{c}1.016 \\
(0.961)\end{array}$ & $\begin{array}{c}0.766 \\
(0.932)\end{array}$ & $\begin{array}{c}0.829 \\
(0.991)\end{array}$ & $\begin{array}{c}0.528 \\
(0.946)\end{array}$ \\
\hline Crisis & $\begin{array}{c}-1.595^{* * *} \\
(0.286)\end{array}$ & $\begin{array}{c}-1.771 * * * \\
(0.320)\end{array}$ & $\begin{array}{c}-2.142^{* * *} \\
(0.406)\end{array}$ & $\begin{array}{c}-1.415^{* * *} \\
(0.315)\end{array}$ & $\begin{array}{c}-1.740 * * * \\
(0.378)\end{array}$ \\
\hline Employment protection & $\begin{array}{l}1.936 * \\
(1.069)\end{array}$ & $\begin{array}{l}-1.267 \\
(2.484)\end{array}$ & $\begin{array}{l}-0.784 \\
(2.509)\end{array}$ & $\begin{array}{c}1.101 \\
(1.066)\end{array}$ & $\begin{array}{c}1.608 \\
(1.138)\end{array}$ \\
\hline Product market regulation & & & $\begin{array}{l}-0.775 \\
(0.590) \\
\end{array}$ & & $\begin{array}{l}-0.647 \\
(0.455)\end{array}$ \\
\hline \multicolumn{6}{|l|}{ First Stage } \\
\hline Excluded instruments: & & & & & \\
\hline $\begin{array}{l}\text { Lagged employment } \\
\text { protection }\end{array}$ & $\begin{array}{c}0.877 * * * \\
(0.085)\end{array}$ & $\begin{array}{c}0.7893 * * * \\
(0.0864)\end{array}$ & $\begin{array}{c}0.7728 * * * \\
(0.0872)\end{array}$ & $\begin{array}{c}0.8660 * * * \\
(0.0908)\end{array}$ & $\begin{array}{c}0.8365 * * * \\
(0.093)\end{array}$ \\
\hline $\begin{array}{l}\text { Government (left) } \\
\text { composition }\end{array}$ & $\begin{array}{c}0.0004^{*} \\
(0.002)\end{array}$ & $\begin{array}{c}0.0004^{* *} \\
(0.002)\end{array}$ & $\begin{array}{c}0.0004 * \\
(0.002)\end{array}$ & $\begin{array}{c}0.0004 * \\
(0.002)\end{array}$ & $\begin{array}{l}0.0003 \\
(0.002)\end{array}$ \\
\hline $\begin{array}{l}\text { Partial R-squared of } \\
\text { excluded instruments }\end{array}$ & 0.6065 & 0.5387 & 0.5217 & 0.5720 & 0.5432 \\
\hline Weak Identification $\mathrm{F}$ test & 0.0064 & 0.0068 & 0.0061 & 0.0064 & 0.0075 \\
\hline Hansen J statistic & 0.7150 & 0.8469 & 0.8589 & 0.6875 & 0.7408 \\
\hline Observations & 389 & 405 & 399 & 347 & 341 \\
\hline R-squared & 0.464 & 0.387 & 0.404 & 0.452 & 0.473 \\
\hline Number of countries & 23 & 28 & 28 & 23 & 23 \\
\hline
\end{tabular}

Robust standard errors in parentheses, *** $p<0.01, * * p<0.05, * p<0.1$

Advanced economy: Australia, Austria, Belgium, Canada, Denmark, Finland, France, Germany,

Greece, Ireland, Italy, Japan, South Korea, Luxemburg, Netherlands, New Zealand, Norway, Portugal,

Spain, Sweden, Switzerland, UK, US

Regression: fixed effect module 